NBER WORKING PAPER SERIES

\title{
HEALTH SHOCKS OF THE FATHER AND LONGEVITY OF THE CHILDREN'S CHILDREN
}

\author{
Dora Costa \\ Working Paper 29553 \\ http://www.nber.org/papers/w29553 \\ NATIONAL BUREAU OF ECONOMIC RESEARCH \\ 1050 Massachusetts Avenue \\ Cambridge, MA 02138 \\ December 2021
}

I have benefitted from the comments of seminar participants at Vanderbilt, UCLA, and University of Duisburg-Essen. I thank Noelle Yetter, Heather DeSomer, Sandra Mason, Coralee Lewis, Heather Giles, Irene Clark, Janice Faulconer, and Annalisa Crain for their tremendous work in creating the datasets. I gratefully acknowledge the support of UCLA and of NIH grants P01 AG10120 and R21 AG064460 and the use of facilities and resources at the California Center for Population Research, UCLA, which is supported in part by NICDH grant P2C HD041022. The views expressed herein are those of the author and do not necessarily reflect the views of the National Bureau of Economic Research.

NBER working papers are circulated for discussion and comment purposes. They have not been peer-reviewed or been subject to the review by the NBER Board of Directors that accompanies official NBER publications.

(C) 2021 by Dora Costa. All rights reserved. Short sections of text, not to exceed two paragraphs, may be quoted without explicit permission provided that full credit, including (C) notice, is given to the source. 
Health Shocks of the Father and Longevity of the Children's Children

Dora Costa

NBER Working Paper No. 29553

December 2021

JEL No. I14,I19,N31,N32

\begin{abstract}
$\underline{\text { ABSTRACT }}$
Whether and how a paternal health shock cascades across multiple generations to affect descendant health is understudied even though a link between ancestral living conditions and descendant health may constitute an important source of differences in the stock of health capital across families and thus across ethnic, racial and social groups. I study how a paternal health shock affects grandchildren's longevity in a unique setting where the ancestral stressor is the grandfather's ex-POW status in the US Civil War (1861-5) and the children are born after the war. Ancestral stress is associated with longevity after age 45 of male-line grandsons but not of granddaughters or female-line grandchildren. I rule out transmission through socioeconomic channels and direct cultural transmission from grandfather to grandson. An epigenetic explanation is consistent with observed male-line transmission at epigenetically sensitive ancestral ages and mediation by own late gestational conditions. Consistent with epigenetic reprogramming depending on the in-utero environment, the association between the veteran's exPOW status and that of his male-line descendants declines across generations.
\end{abstract}

\author{
Dora Costa \\ Bunche Hall 9272 \\ Department of Economics \\ UCLA \\ Box 951477 \\ Los Angeles, CA 90095-1477 \\ and NBER \\ costa@econ.ucla.edu
}


There is growing concern that health can be transmitted across generations, leading to the persistence of poor health within families. Exposure of mothers to famines, infection, and psychological stress during pregnancy has been linked to poor health of children at birth and in adulthood (Barker, 1992, 1994; Lumey and van Poppel, 2013; Veenendaal et al., 2013; Heijmans et al., 2008; Almond, 2006; Currie and Rossin-Slater, 2013; Class et al., 2011, 2014; Persson and Rossin-Slater, 2018). Whether and how a paternal health shock cascades across multiple generations to affect descendant health is understudied even though a link between health and ancestral living conditions may constitute an important source of differences in the stock of health capital across ethnic, racial and social groups. Ancestral conditions, as embodied in the health stock of people, may account for some of the associations observed between place and health, associations which are not fully explained by health behaviors (Chetty et al., 2017), medical care (Finkelstein et al., 2021), or own early life conditions (Barker, 1992).

This paper provides evidence for male-line transgenerational transmission of a paternal shock affecting longevity in a unique settting where the ancestral stressor is the grandfather's ex-POW status in the US Civil War (1861-5). Grandfathers' POW experience represents extreme stress, inflicted on soldiers in an as good as random manner. Conditions in Civil War POW camps deteriorated sharply when prisoner exchanges stopped, leading to starvation, disease, and death. I document transgenerational transmission by following grandchildren descended from children born after the war to Union Army veterans. Descendants of grandfathers who were non-POW veterans and former POWs imprisoned when camp conditions were better provide controls for descendants of ex-POWs imprisoned when camp conditions were at their worst. 
Mechanisms for transgenerational transmission include biological, socioeconomic, and cultural or psychological factors. Plant and some animal studies support transgenerational transmission through epigenetic imprinting, a heritable modification of gene expression, but epigenetic imprinting is species-specific and evidence in human populations is limited because of data needs, requiring controls for social and cultural factors and at least two generations whose ancestors experienced a post-natal shock or three generations whose ancestors experienced an in-utero shock (Heard and Martienssen, 2014).

There are only three sets of transgenerational studies of human populations, all examining ancestral shocks during the vulnerable slow growth period prior to puberty. The most famous studies use grandparents' harvests in Överkalix, Sweden (Kaati et al., 2007; Bygren et al., 2001). One other study uses harvests affecting the grandparents of residents of Uppsala, Sweden and another study uses the WWI German famine (Vågerö et al., 2018; Van den Berg and Pinger, 2016). The studies provide indirect evidence of epigenetic paternal transgenerational transmission but the limited geographic scope of these studies, underpowered samples, and some contradictory findings raise the possibility that the observed transgenerational effects could be due to chance findings or to other confounders. ${ }^{1}$

I provide indirect evidence of paternal epigenetic transgenerational transmission using a study design which provides high statistical power, clear treatment and control groups, a rich array of social controls, the necessary variation to rule out specific pathways of transmission, and minimal confounding from other stressors both because POW stress

\footnotetext{
${ }^{1}$ I estimate power in the Överkalix studies to detect the authors' estimated hazard ratio of 1.45 to be 0.66. The corrected estimate of power to detect a hazard ratio of this magnitude in the Uppsala Multigen Study is 0.48 (Vågerö et al., 2021). Although the Överkalix sample contains only 164 male-line grandsons while the Uppsala Multigen sample contains 3,224 male-line grandsons, few grandsons have completed lifespans and only $5 \%$ of grandfathers experienced the harvest shock during their slow growth periods.
} 
was extreme and because it was orthogonal to other health shocks. Male-line grandsons of ex-POWs who experienced a harsh captivity were 1.1 times more likely to die at any age after age 45 compared to the male-line grandsons of non-POWs. The magnitude of this ancestral risk was greater than the mortality risk of having a father who was a laborer or of experiencing low nutritional availability during late gestation as proxied by quarter of birth. I can rule out transmission through socioeconomic channels and direct cultural transmission from grandfather to grandson. Transmission to male-line grandsons only and the sensitivity of the transmission to epigenetically sensitive ancestral ages and to own late gestational conditions as proxied by quarter of birth is more consistent with an epigenetic rather than other explanations, including direct or indirect social or cultural transmission.

My findings, by providing "proof of concept" for paternal transmission have implications which extend beyond my setting and encompass paternal epigenetic changes due to health behaviors such as smoking, heavy drinking, or over-eating. Because of the developmental origins of disease thesis (Barker, 1992, 1994), the health behaviors of pregnant women have been scrutinized whereas those of young men have not. Dependence of paternal transmission on the environment suggests epigenetic changes arising from health behaviors may be reinforced by cultural transmission of the same health behaviors. Genomewide association studies therefore should account not only for heterogeneity in the current environment as in Rosenquist et al. (2015) but also in ancestors' environments. My findings suggest that paternal transmission of ancestral living conditions or health behaviors is likely to be a fruitful avenue for future research on therapies targeting the epigenetic components of chronic disease and on policies aimed at reducing health inequalities.

My results speak to our understanding of the health transition, that is, the shift from a 
high mortality regime where infectious diseases were common to a low mortality regime dominated by chronic conditions. Scholars have debated the relative roles of public health and of nutritional improvements in the health transition in today's developed countries (Floud et al., 2011; Deaton, 2013; Cutler et al., 2006; Costa, 2015; Alsan and Goldin, 2019). If chronic disease arises in part from ancestral living conditions, the rising incomes and agricultural productivity which preceeded the public health revolution and which enabled better nutritional intake have a long reach. The epigenetic legacy of ancestral living conditions may be particularly relevant for understanding health patterns in developing countries which only recently have experienced improvements in life conditions (Luke et al., 2021).

\section{Transgenerational Transmission}

Biological pathways for transmission of paternal health shocks include mutations to the DNA of sperm, viruses or prions in seminal fluid and epigenetic imprinting arising from DNA methylation, RNA modification, or histone modification. Of these biological processes only epigenetic imprinting is sex-specific. Transmission of an epigenetic effect along the Y chromosome, as hypothesized in the Överkalix studies (Bygren et al., 2001), predicts a correlation between grandfathers' ex-POW status and the mortality of his maleline grandsons but not with the mortality of his male-line granddaughters or of his femaleline grandchildren. Different ages have been proposed as epigenetically senstive time points, including just prior to conception, in utero when epigenetic reprogramming occurs, the slow growth period before adolescence when gametes are forming in boys, and times of hormonal changes, including peak height in adolescence and the later slowdown 
in growth, and aging. Because Union Army soldiers were growing rapidly until age 21 and then more slowly until age 25 (Wilson and Pope, 2003), epigenetic changes should occur disproportionately among veterans who were less than age 25 at the time of captivity.

Epigenetic markings persist across generations because of altered epigenetic reprogramming early in gestation during the period of DNA methylation erasure or disruption of epigenetic reprogramming in the second half of gestation (Baxter and Drake, 2019). Male primordial germ cells (PGCs) undergo extensive epigenetic reprogramming in late gestation. Inadequate maternal nutrition resulting from seasonality in food and vitamin availability during late gestation, when more demands are made on maternal nutrition, may delay or impair remethylation.

Socioeconomic pathways for transmission predict that grandfathers' ex-POW status will be correlated with the mortality of all grandchildren, not just with that of male-line grandsons, and that grandfathers' ex-POW status will be more strongly correlated with grandchildrens' mortality when the grandfather experienced a health shock at an older age. If human capital is occupation or industry specific (Kambourov and Manovskii, 2009; Neal, 1995; Parent, 2000), standard human capital and occupational matching models predict that the opportunity cost of switching occupations or industries rises with age and that health shocks at older ages lead to worse socioeconomic outcomes, a prediction borne out in comparisons of post-war occupational changes of wounded and non-wounded Union Army veterans (Costa et al., 2020).

Direct grandpaternal cultural influence should extend to all grandsons, regardless of descent from sons or daughters, and requires geographical proximity. Indirect cultural influence from the veteran to his son is unlikely because the veteran's ex-POW status was 
more closely correlated with his sons' mortality when sons faced inadequate nutrition inutero (as proxied by quarter of birth), a correlation more consistent with an epigenetic rather than a cultural explanation (Costa et al., 2018).

Selective survival in POW camps could account for transmission of a grandfather's stress to children but such an explanation would not lead to sex-specific longevity patterns. While camp conditions were the primary determinants of survival, older men, the tall, those with a lower military rank, farmers, and those with fewer comrades in the camp were less likely to survive (Costa and Kahn, 2007). Additionally, a genetic variant which permitted survival in starvation conditions could be harmful when conditions improved.

Selection into marriage with spouses in poorer health or of lower socioeconomic status is an additional explanation for transgenerational transmission. Such selection implies worse mortality outcomes by father-in-law's ex-POW status among the parents of veterans' grandchildren but would not have any sex-specific implications for their children.

Epigenetic reprogramming should lead to a declining association between the veteran's ex-POW status and the longevity of his sons compared to that of his male-line grandsons. The strength of the relationship between a veteran's ex-POW status and his son's longevity depended on his quarter of birth, with sons born in the second relative to the fourth quarter facing the highest risk (Costa et al., 2018). If one quarter of sons of sons were born in each quarter and if the full quarter of birth hazard by ex-POW status was transmitted only to sons born in the second quarter, the association between male-line grandsons' longevity and veterans' non-exchange ex-POW status relative to non-POW status should be half what it was for their fathers. ${ }^{2}$ A caveat to this calculation is that differential mortality

\footnotetext{
${ }^{2}$ Relative to sons of non-POWs born in the same quarter, the hazard ratios for sons of non-exchange
} 
selection and disease environments (e.g., less noise from infectious disease in later cohorts) could lead to a stronger observed association among grandsons than among sons.

\section{Methods}

Identification of the relationship between grandfathers' trauma and their grandchildren's longevity depends on the comparison of descendants of non-POW veterans and ex-POWs captured during the prisoner exchange period (before July 1863 or after June 1864) and the non-exchange period (between July 1863 and July 1864). Most POWs were exchanged immediately until mid-1863 when prisoner exchanges stopped as the two sides argued over the terms, particularly the treatment of black soldiers (who could be enslaved) and their white officers (who could be hanged as the leaders of a slave insurrection). Men captured after mid-1863 faced more time in captivity and ever worsening conditions as the crowds of prisoners increased. Crowding at Andersonville, the most notorious Confederate camp, began to improve in September with transfers to other prison camps and unofficial exchanges (Marvel, 1994). Official exchanges began again in December of 1864. Among survivors to 1900 from a random sample of Union Army infantry soldiers, wartime records mention scurvy for $11 \%$ of all non-POWs; $14 \%$ of ex-POWs captured before July 1863; 23\% for ex-POWs captured between July 1863 and July 1864; and 14\% for ex-POWs

ex-POWs were 1.07, 1.20, 1.11, and 1.07 for each quarter of birth (Costa et al., 2018). Assume that the hazards for the sons of sons born in the second quarter were the same (1.07, 1.20, 1.11. and 1.07), leading to an average hazard for the son of a son born in the second quarter to be 1.11. Similarly, assume that average declines for sons of sons born in other quarters were similar (e.g., for a son born in the first quarter, his sons' hazard would be 1.02, 1.07, 1.04, and 1.02 for an average of 1.04). Average declines in the association between ex-POW status and across generations therefore would be $55 \%$. 
captured after June 1864 (Costa, 2012). ${ }^{3}$ Among ex-POWs who survived to 1900, average time in captivity was 16 days for men captured before July 1863, 231 days for non-exchange period ex-POWs, and 125 days for men captured after June 1864.

How valid is using non-POWs and exchange ex-POWs as control groups for nonexchange ex-POWs? Concerns that exchange POWs were partially "treated" suggests comparing descendants of non-exchange ex-POWs with descendants of non-POWs. Worries about selection on unobservables in who is captured suggests comparing descendants of non-exchange ex-POWs with descendants of exchange ex-POWs. ${ }^{4}$ Both comparisons most likely underestimate the true mortality cost of descending from a grandfather who experienced extreme stress because of selective within camp survival of the hardiest nonexchange ex-POWs. In a sample of POWs, $4 \%$ of men captured before July 1863 died in captivity versus $27 \%$ captured July 1863 or later (Costa and Kahn, 2007).

I examine the association between grandchildren's longevity and the grandfather's nonexchange ex-POW status relative to the grandfather's exchange ex-POW status within subsamples consisting of male-line grandsons, male-line granddaughters, female-line grandsons, and female-line granddaughters. I fit Cox proportional hazard models, clustered on the veteran grandfather and stratified on birth cohort, to obtain hazard ratios. I specify

$$
h(t)=h_{0}(t) \exp \left(\beta_{x} X\right)
$$

where $t$ is years lived after age $45, h_{0}(t)$ is the baseline hazard and $\mathrm{X}$ is a vector of char-

\footnotetext{
${ }^{3}$ Scurvy develops after 8-12 weeks of vitamin C deficiency.

${ }^{4}$ I have not uncovered anything in the historical record to suggest that men who surrendered in different time periods were different from their comrades who were not captured. Men were captured in groups when officers made the decision to surrender or individually in the chaos of battle or on scouting missions.
} 
acteristics specific to each grandchild. I specify $\beta_{x} X$ as

$$
\beta_{0}+\beta_{1} P_{E}+\beta_{2} P_{N}+\beta_{3} C
$$

where $P_{E}$ and $P_{N}$ are dummy indicators equal to one if the grandfather was an exchange period POW or a non-exchange period POW, respectively, and C is vector of control characteristics. I control for enlistment characteristics of the grandfather and for the grandchild's year of birth. I cannot pool grandsons and granddaughters and still maintain the proportional hazards assumption, perhaps because of differences in mortality patterns by sex among these cohorts.

I investigate the impact of ex-POW status on the mortality of grandsons and granddaughters across male and female lines to control for unobserved differences by ex-POW status. I run two separate regressions for grandsons and granddaughters and interact exPOW status with a dummy indicator for male-line, M,

$$
\beta_{0}+\beta_{1}\left(M \times P_{E}\right)+\beta_{2}\left(M \times P_{N}\right)+\beta_{3} C .
$$

For each ex-POW status type (N=non-exchange, $\mathrm{E}=$ exchange, $0=$ non-POW), I then estimate the hazard ratios for the male-line grandchild relative to the female-line grandchild: $D_{P O W=N}, D_{P O W=E}$, and $D_{P O W=0}$. Because male-line and female-line samples may differ on unobservables, I compare the difference in hazard ratios across male and female line grandchildren for non-exchange ex-POWs to those for other ex-POW status types, i.e. I double-difference to obtain $D_{P O W=N}-D_{P O W=0}$ and $D_{P O W=N}-D_{P O W=E}$. 
I establish if sex patterning in transgenerational transmission arises from social patterning by modifying Equation 1 to control for the veteran's socioeconomic status after the war, the socioeconomic status of the grandchild's father, the number of siblings, and indicators of the physical proximity of the grandchild to the veteran during childhood. I stratify both on birth cohort and census region of birth to control for cohort and region characteristics.

An epigenetic, but not socioeconomic or genetic, explanation implies that the effects of ex-POW status should be concentrated among the descendants of ex-POWs who were POWs at epigenetically sensitive ages. I therefore run Equation 1 on a subsample of grandchildren, restricted to those grandchildren descended from veterans who were at risk of being non-exchange ex-POWs between ages 17 and 24 (inclusive), omitting ages less than 17 because of few observations.

Transgenerational transmission should be more likely when grandchildren's in-utero nutrition is inadequate because reprogramming does not occur. I therefore interact the grandfather's ex-POW status with the grandson's quarter of birth, which for these cohorts proxies for late gestational maternal nutrition (Doblhammer and Vaupel, 2001), to estimate

$$
\beta_{0}+\beta_{1}\left(Q_{i} \times P_{N}\right)+\beta_{2}\left(Q_{i} \times P_{E}\right)+\beta_{3} C
$$

where $Q_{i}$ represents each quarter $i$. While the ideal specification would have allowed for interactions between veterans' sons' quarters of birth and male-line grandsons' quarter of birth, in a sample with relatively few non-POW descendants I do not have good ex-POW and non-POW descendant matches on quarter of birth. 
I test whether veterans' children married short-lived spouses (and hence had shorted lived children) if their fathers were non-exchange ex-POWs rather than non-POWs. While an association between the veteran's ex-POW status and the mortality of his children-inlaw could reflect unmeasured socioeconomic status, no association suggests no marriage selection and no unmeasured socioeconomic status effects for veterans' children.

I investigate how the association between ancestral ex-POW stress and longevity changes across the generations by running a modified version of Equation 1 for separate samples of veterans' sons and veterans' male-line grandsons where each male-line grandson lived to age 45 and had a father who lived to age 45 . Recall that I predicted a decline of $55 \%$ in the association between the veteran's ex-POW status and descendant longevity across generations.

Parents' longevity is a proxy for their health or the stress of a parental death, both of which could directly affect the health of children. Because the longevity of fathers descended from veterans depends on the veteran's ex-POW status, I conduct a formal mediation analysis in which I control for both parents' longevity and treat the father's longevity as a mediator. Using a counterfactual approach, I specify the grandson's expected longevity (Y) given the veteran's ex-POW status (the treatment, D), the mediator (M) of his father's longevity, and controls (C) as

$$
E[Y \mid D, M, C]=\theta_{0}+\theta_{1} D+\theta_{2} M+\theta_{3}(D \times M)+\theta_{4} C
$$


and his father's expected longevity, the mediator, as

$$
E[M \mid D, C]=\beta_{0}+\beta_{1} D+\beta_{2} C
$$

I estimate Equation 4 using a Cox proportional hazards model and Equation 5 using a linear equation and set the values of the control variables to their means and the value of father's longevity to age 72. I run separate equations for 1) non-exchange ex-POWs and non-POWs and 2) non-exchange and exchange ex-POWs. I then calculate the proportion of the total effect due to mediation with the father's longevity (natural indirect effect) and the mediated interaction. ${ }^{5}$ The identification assumption is that there are no unobserved confounders jointly affecting grandsons and sons longevity, i.e. no post-captivity confounders.

\section{Data}

My three generation sample consists of Union Army veterans who survived to 1900, their children, and grandchildren. The sample contains contains 1,444 ex-POWs, their 8,190 children, and their 17,015 grandchildren and 1,381 non-POWs, their 8,596 children, and their 18,6588 grandchildren.

I constructed the unique transgenerational sample to oversample the grandchildren of ex-POWs by building on databases of Union Army veterans and their children (see Appendix A for details). I followed the children of veterans through birth, death, and census

\footnotetext{
${ }^{5}$ See the discussions by Celli (2021) and Belloco (2021).
} 
records, tracing the children of all ex-POWs and of a subsample of non-POWs matched on ex-POW demographic, geographic and socioeconomic characteristics at enlistment. Most children were born after the war.

I created the sample of veterans' grandchildren by obtaining birth and death information for grandchildren of all ex-POWs and of a subsample of non-POWs, matached on the enlistment characteristics of ex-POWs. I restricted the search to grandchildren of veterans with at least one child who survived to age 45 and who was born after the war but followed all grandchildren regardless of parent's age at death.

All veterans and veterans' children were linked to the 1850-1940 censuses, with the exception of the 1890 census which was destroyed by fire. Ninety-eight percent of veterans and $86 \%$ of their children are linked to at least one census. Veterans' grandchildren are in a census because they were in their parents' households. Conditional on being alive and younger than age 18 at the time of the census, $92 \%$ of children are linked to a census (see Appendix A for details).

The sample is primarily a Northern sample, as expected from one descended from Union Army veterans. Twenty-two percent of grandchildren were born in the Northeast and $58 \%$ were born in the North Central region. Among the $92 \%$ of grandchildren with death dates, life expectancy of grandchildren of either sex at age 10 or greater was higher by about a year compared to that observed in Social Security area cohorts, probably because grandchildren were native-born and were concentrated in the more rural Midwest (see Appendix A).

There are many selection stages leading to a veteran's grandchild being in the final sample. Veterans had to survive the war, including POW camps, and they had to survive 
to 1900 . They had to marry and have children. Veterans' children had to survive to age 45. Each of these selection stages suggests that I may be underestimating the full association between a grandfather's ex-POW status and the mortality of his descendants because only the hardiest POWs and their children survived and only the hardiest ex-POWs married. Ex-POWs were more likely to have no children than non-POWs (12\% versus $9 \%)$ but among those who did have children there was no difference in the number of children $(5.2$ each). Sons and grandsons are slightly over-presented in the sample: $53 \%$ of the veterans' children are sons and $51 \%$ of the veterans' grandchildren are grandsons.

My analytical sample consists of all grandchildren who survived to age 45 and who descended from children born after the war. The sample contains 24,531 grandchildren from 13,959 children of 2,825 veterans (see Figure A1 in Appendix A for a break-down by veteran's ex-POW status and descendant line). I exclude observations with age inconsistencies and I treat the nine living grandchildren in the sample as censored. ${ }^{6}$

What are the implications of restricting the sample to grandchildren who survived to age 45? Within my sample, the association between grandchildren's mortality and grandfathers' non-exchange ex-POW status is evident only after age 45 and only for male-line grandsons (see Appendix A). However, deaths prior to age 10 are underestimated in my sample and I find suggestive evidence that early childhood mortality was higher among male-line grandchildren of non-exchange ex-POWs compared to female-line grandchildren or grandchildren of non-POWs (see Appendix A). I thus am underestimating the full association between a grandfather's ex-POW status and the mortality of his male-line de-

\footnotetext{
${ }^{6}$ There were too few grandchildren of children born after the war to compare longevity across descendants of veterans with children born before and after the war even when the extant sample was expanded.
} 
scendants.

\subsection{Variables}

My control variables consist of three types: those which control for pre-war differences between grandfathers, those which control for post-war differences between grandfathers and parents, and those which control for differences between grandchildren. Pre-war differences between grandfathers include year of enlistment (which I treat as a dummy variable), occupation at enlistment (farmer, artisan, laborer, and unknown with professional and proprietor as the omitted category), enlistment in a city of 50,000 or more (i.e., one of the 13 largest and thus deadliest cities in the US in 1860), born in the US, and wounded in the war. Although I used these variables and age of enlistment to pick matched control non-POWs for the ex-POWs using a propensity score, ex-POWs were more likely to be urban, less likely to be farmers, and more likely to have enlisted earlier than non-POWs (see Table 1). Exchange ex-POWs had some of the pre-war characteristics of non-exchange ex-POWs (e.g., fraction enlisting in 1861) but more closely resembled non-POWs in other characteristics (e.g., fraction who were laborers). Because there may be unobserved differences between the Union Army sample and the Andersonville sample, I also control for whether the veteran was from the Union Army sample.

My controls for post-war differences between grandfathers are occupation in 1880 (farmer, professional or proprietor, artisan, laborer, no occupation, and not found in the census). Non-exchange ex-POWs were less likely to be farmers and were more likely to be artisans than non-POWs or exchange ex-POWs (see Table 1). I control for grandchil- 
dren's childhood socioeconomic status with dummy variables indicating if the father (the veteran's son or son-in-law) was ever a laborer, a farmer, or a property owner. Male-line grandchildren of non-exchange ex-POWs were slightly less likely to have a father who was a farmer and more likely to have a father who was never a homeowner than the grandsons of non-POWs but there were no such differences for female-line grandchildren. There were no differences in fathers' laborer status by grandfathers' ex-POW status (Table 2).

I control for differences between grandchildren with birth year, birth cohort, the number of siblings, and dummy variables indicating whether the veteran grandfather ever lived in the same household as the grandchild and whether the living veteran grandfather ever was in the same county as the grandchild (for variable means see Table 2). The latter two variables could proxy for the grandfather's longevity, socioeconomic status or for a direct influence of the grandfather on the grandchild. However, direct influence is likely to be minimal because opportunities for contact were few. Only a third of grandchildren ever lived in the same county as their non-exchange ex-POW grandfathers and only $4 \%$ ever lived in the same household.

I use parents' longevity after age 45 as the dependent variable to examine both the health of male-line grandsons' mothers by the veteran's ex-POW status and changes in the association between ancestral ex-POW status and descendant longevity across generations. I also use parents' longevity (without the age restriction in Table 2) as a proxy for their health in a mediation analysis. 


\section{Mortality Results for Grandchildren}

Male-line grandsons who lived to age 45 lived, on average, 1 year less if they descended from a non-exchange ex-POW rather than from an exchange ex-POW or a non-POW (73 versus 74 years, see Table 3). I do not observe differences among other lines. Among male-line grandsons of non-exchange ex-POWs matched to grandsons of non-POWs on grandfather characteristics at enlistment, the average treatment effect on the treated was -1.05 years and the average treatment effect was -0.84 years when I compared descendants of non-exchange ex-POWs with those of non-POWs (see Table 3 and see the notes therein). The treatment effects were statistically significant at the 1 and $5 \%$ level, respectively. Comparing male-line grandsons descended from non-exchange ex-POWs with those descended from exchange ex-POWs yielded an average treatment effect on the treated and an average treatment effect of 0.7 years but the effects were not statistically significant. Treatment effects in other lines were small and statistically insignificant. To include all observations, to control for grandchildren's birth cohort and to compare across male and female lines to account for unobserved differences between ex-POW status groups, I estimate Equations 1 and 2.

Grandsons of male-line non-exchange ex-POWs were 1.11 times more likely to die at any age after age 45 than the male-line grandsons of non-POWs, controlling for birth year and the grandfather's characteristics at enlistment and stratifying on birth cohort (see Table 4, which presents estimates of Equation 1). They were 1.08 times were more likely to die any age after age 45 than the male-line grandsons of exchange ex-POWs. The hazard ratios were statistically significant at almost the $1 \%$ and at the $5 \%$ level, respectively. There 
were no statistically significant differences among male-line granddaughters and femaleline grandchildren by grandfathers' ex-POW status.

Controlling for unobserved differences across ex-POW status groups by first comparing male- and female-line grandsons and granddaughters within ex-POW status groups (see Equation 2) and then comparing across ex-POW types, yields double-differences which show that male-line grandsons of non-exchange ex-POWs were 1.12 times more likely to die than the male-line grandsons of non-POWs and 1.14 times more likely to die than the male-line grandsons of exchange ex-POWs $\left(D_{P O W=N}-D_{P O W=0}\right.$ and $D_{P O W=N}-$ $D_{P O W=E}$ in Table 5). The results were statistically significant at almost the 1 percent level. Among descendants of non-exchange ex-POWs, a male-line grandson was 1.08 times as likely to die at any age after age 45 than a female-line grandson $\left(D_{P O W=N}\right)$ ), a result which was statistically significant at the $6 \%$ level, whereas there were no differences by line among granddaughters. The double-difference estimates are preferred if there is selection into specific lines, including because of the difficulty of tracing women who marry and change their names.

The sex-specificity of the relationship between grandfather's ex-POW status and the longevity of his grandchildren persists when I restrict the sample to the eldest grandchild within each line. This restriction both avoids potential correlation between siblings not captured by clustering on the grandfather and it controls for within-sex birth order conditional on survival to age 45. Appendix B (section B.1) shows that male-line grandsons of non-exchange ex-POWs were 1.14 times as likely to die at any age after age 45 than their counterparts descended from ex-POWs and 1.13 times as likely to die than their counterparts descended from exchange ex-POWs. The results were statistically significant at the 
$1 \%$ and $5 \%$ level, respectively.

I find suggestive evidence that some of the non-exchange ex-POWs were partially treated. When I divided the exchange ex-POW category into those captured early (prior to July 1863) and those captured late (after June 1864), I found that male-line grandsons were statistically significantly 1.13 times more likely to die at any age after age 45 if descended from a non-exchange ex-POW rather than a POW was captured in the early days of the war (see Appendix B, section B.2). Male-line grandsons descended from exchange ex-POW who were captured late in the war were 1.06 times as likely to die at any age after age 45 compared to the descendants of non-POWs or of exchange ex-POW captured early in the war, but the hazard ratio was not statistically significant.

\subsection{Mechanisms}

I rule out socioeconomic factors and grandfathers' direct cultural influences as transmission mechanisms because the results in Table 4 persist when I control for the socioeconomic characteristics of the grandchild's father and for the geographical proximity of the veteran to his grandchild and when I stratify both on birth cohort and region of birth (see Table 6). The grandsons of male-line non-exchange ex-POWs were 1.10 and 1.07 times more likely to die at any age after age 45 than the male-line grandsons of non-POWs and exchange ex-POWs, respectively. However, compared to the results without socioeconomic controls statistical significance on the comparison between non-exchange ex-POWs

and exchange ex-POWs falls from 5 to 10 percent. A grandfather's ex-POW status remains unrelated to his granddaughters' mortality. 
Table 6 reveals that the relationship between a grandfather's ex-POW status and his male-line grandsons' mortality was on par with the association between the father's socioeconomic status and his son's older age mortality. A male-line grandson was 1.08 times more likely to die at any age after age 45 if the father was ever a laborer and was 0.92 times less likely to die if the father was ever a farmer. He was 1.12 times more likely to die if his father was never a home owner. Paternal socioeconomic status was correlated with the mortality of all grandchildren, not just male-line grandsons, implying that any socioeconomic effects due to a grandfather's ex-POW status should affect daughters as well. Having the veteran in the same county or the same household as the grandchild was not correlated with grandchildren's mortality (coefficients not shown).

Contrary to a socioeconomic explanation, but consistent with an epigenetic explanation, the association between a grandfather's non-exchange ex-POW status and his grandsons' mortality relative to non-POWs is seen only among the grandsons of veterans who were at risk of being imprisoned as non-exchange POWs when they were between ages 17 and 24 (see Table 7). Controlling for the grandfather's pre-war characteristics and the grandchild's birth year, and stratifying on birth cohort, the male-line grandson of a nonexchange ex-POW was 1.22 times as likely to die at any age after age 45 as the male-line grandson of a non-POW and 1.10 times as likely to die at any age as the male-line grandson of an exchange ex-POW.

Consistent with an epigenetic explanation, but not with indirect cultural transmission, poor in-utero conditions, as proxied by quarter of birth, may mediate grandfathers' exPOW stress among male-line grandsons (Table 8). Male-line grandsons descended from ex-POWs born in the first half of the year were 1.15 to 1.17 times more likely to die at any 
age after 45 than male-line grandsons descended from non-POWs. In contrast, there was no statistically significant relationship between ex-POW status and grandsons' longevity among grandsons born in the second half of the year. I did not find a statistically significant relationship between male-line grandsons longevity after age 45 and grandfathers' non-exchange ex-POW status relative to exchange ex-POW status; however, the magnitude of the findings suggests that among grandsons born in the first half of the year those descended from non-exchange ex-POWs were 1.11 times as likely to die as grandsons descended from exchange ex-POWs.

There were no health differences between the mothers of male-line grandsons who married the sons of non-exchange ex-POWs rather than the sons of non-POWs (see Ap-

pendix B, section B.3). The absence of a difference confirms that were no unobserved family factors increasing mortality in the households of male-line grandsons.

\section{Mortality Across Generations}

The relationship between veterans' non-exchange ex-POW status and their male-line descendants' mortality attenuates across two generations who survived to age 45 . Sons of non-exchange ex-POWs who survived to age 45 and who had a son who survived to age 45 were 1.17 times as likely to die at any age after age 45 compared to sons of non-POWs and 1.10 times as likely to die compared to sons of non-exchange ex-POWs (see Table 9). Their sons (the veteran's male-line grandsons) were 1.10 times as likely to die at any age after age 45 compared to the male-line grandsons of non-POWs, a $39 \%$ decline in the association between longevity and the veteran's non-exchange ex-POW relative to non-POW 
status on male-line descendants across generations. Male-line grandsons were 1.08 times as likely to die at any age after age 45 if they descended from non-exchange ex-POWs relative to exchange ex-POWs, a $13 \%$ decline in the association between longevity and non-exchange ex-POW status relative to exchange ex-POW status. In contrast, while veterans' sons who fathered daughters were 1.15 times as likely to die at any age after age 45 compared to the sons of non-POWs, there was no statistically significant relationship between veterans' ex-POW status and male-line granddaughters' mortality.

\section{Paternal Longevity as a Mediator}

Indirect effects of ex-POW status operating through the father's health, effects which arguably could arise from cultural or social factors, account for at most $18 \%$ of the association between grandfathers' non-exchange ex-POW status relative to non-POWs and maleline grandsons' longevity among all male-line grandsons and $6 \%$ of the association among male-line grandsons descended from veterans at risk of being non-exchange ex-POWs between ages 17 and 24 (see Table 10). Estimated indirect effects are similar in the two samples. The difference is in estimated direct effects. If I had set all veterans' sons health to a level such that their longevity would be 72 years, the relative excess risk of grandsons descended from non-exchange ex-POWs relative to non-POWs would be 0.08 among all male-line grandsons and 0.16 among grandsons descended from veterans at risk of being non-exchange ex-POWs at younger ages. The total excess mortality risk of descending from a non-exchange relative to an exchange ex-POW is not statistically significantly different from 0. My analysis implies that my hazard rates of a 1.11 and a 1.22 greater risk 
of dying at any age after age 45 for male-line grandsons descended from non-exchange ex-POWs relative to non-POWs for the full sample and the sample restricted to male-line grandsons of veterans at risk of being non-exchange ex-POWs between ages 17-24, would fall, respectively, to at most 1.09 and 1.20.

\section{Discussion}

There are three major differences between this study and prior research on mortality postulating an epigenetic explanation for ancestral transmission. The first is that I find a negative association between an adverse shock and subsequent mortality whereas the prior studies emphasize a positive association. The second is that the ancestral stress occurs in young adulthood rather than during the slow growth years prior to puberty. The third is that I find a declining relationship between a grandfather's ancestral stress and his sons' and male-line grandsons' longevity whereas prior work suggest that transmission skips a generation.

The positive association between a grandfather's harsh captivity experience and his male-line grandson's mortality contrasts with the negative association observed in Sweden between the paternal grandfather's harvest experience during his slow growth period and his male-line grandsons’ mortality (Kaati et al., 2007; Vågerö et al., 2018). These somewhat counterintuitive results, which imply that is beneficial to have had ancestors who experienced hunger, may arise because it is not the level of grandfathers' harvests which affects grandsons' mortality but rather the change in grandfathers' harvest types. Bygren et al. (2014) find a relationship between granddaughters' mortality and change 
during the slow growth period in paternal grandfathers' harvest type from an unusually good to unusually bad type or vice-versa. They raise the possibility that radical change in food availability induces gene expression responses and epigenetic processes. POWs experienced a rapid deterioration to starvation levels and then a return to good conditions. ${ }^{7}$

Transmission effects concentrated at ancestral risk ages of 17-24 are consistent with Bygren (2013) reporting that a grandfather's poor harvest circa age 19 in Överkalix was associated with elevated mortality among his male-line grandsons and with his hypothesis that epigenetic changes due to nutritional intake are more likely during ths slow rather than fast growing periods because body size responds to food availability at times of fast growth. When I examine male-line grandsons by two year ancestral age groups to compare the longevity of those descended from non-exchange ex-POWs to those descended from ex-POWs, I find that those grandsons descended from grandfathers who were non-exchange ex-POWs between ages 19-24 were at greatest risk (see Appendix B, section B.4).

The declining assocation between veterans' ex-POW status and the longevity of their sons and male-line grandsons differs from the generational skipping observed in the Swedish data. Abstracting from cohort effects, I predicted a 55\% decline in intergenerational transmission because of the interaction between epigenetic and quarter of birth effects and estimated a 39\% decline. My results imply that when conditions are poor, associations between ancestral stress and descendant longevity should be greater across generations and should persist over more generations.

My estimates of transgenerational mortality transmission are smaller than those ob-

\footnotetext{
${ }^{7}$ I thank Olov Bygren for suggesting this hypothesis.
} 
served both in the Överkalix and in the Uppsala Multigen Study. In Överkalix, male-line grandsons whose grandfathers experienced a good harvest during their slow growth period prior to puberty were 1.45 times as likely to die at any age compared to those whose grandfathers had experienced a normal harvest. If their grandfathers experienced a poor harvest circa age 19, their risk of death was more than 1.5 times higher (Bygren, 2013). In the Uppsala Multigen Study, male-line grandsons whose grandfathers had experienced an unusually good harvest were 1.5 times as likely to die at any age compared to those whose grandfathers had experienced a normal harvest (Vågerö et al., 2018). While the types of shocks, the timing of the shocks, and the environments in which grandchildren grew up differ across my sample and the Swedish samples, I cannot exclude differences because of comparisons with chance findings or because of greater mortality selection in my sample. ${ }^{8}$ Estimates of intergenerational transmission from veterans to sons in Table 9 may be larger than those in Costa et al. (2018) because this sample is better matched on veteran characteristics.

The risk to male-line grandsons' longevity posed by grandfathers' harsh captivity conditions are on a par with those posed by in-utero risks and paternal socioeconomic status. Appendix B (section B.5) shows that grandsons descended from non-POWs were 1.07 times more likely to die every age after age 45 if they were born in the second relative to the fourth quarter. Recall that a male-line grandson whose father was ever a laborer or never a farmer was 1.08 times more likely to die at any age after 45 compared to a male-

\footnotetext{
${ }^{8}$ The power in my study to detect the estimated hazard ratio of 1.11 is 0.91 and the power to detect a hazard of 1.22 in the subsample restricted to grandsons of veterans at risk to be non-exchange ex-POWs is 0.98. As noted in footnote 1, power in the Överkalix studies to detect a hazard ratio of 1.45 is 0.66 and power to detect a hazard ratio of this magnitude in the Uppsala Multigen Study is 0.48.
} 
line grandson whose father was never a laborer or ever a farmer. If his father was never a home owner, he was 1.12 times as likely to die (Table 6). Relative to male-line grandsons descended from non-POWs, male-line grandsons descended from non-exchange ex-POWs lost a median 1.22 years of life and 2.22 years if their grandfathers were at risk of being non-exchange ex-POWs between ages 17 and 24 (see Appendix B, section B.6.) Relative to male life-expectancy of 28.05 at age 45 in the 1910 cohort Social Security Area life tables (Bell and Miller, 2005), the respective loss of life expectancy was 4 and 8\%. In comparison, men age 50-54 in 1992 lost two years of life if they were current smokers and gained 0.24 years of life if they were college rather than high school educated (Østbye and Taylor, 2004).

I suspect that I do not observe effects operating through parental socioeconomic channels because health declines among sons occurred after socioeconomic status was established. Appendix B (section B.7) shows that although non-exchange ex-POWs shifted out of farming after the war relative to non-POWs and exchange ex-POWs, the occupational shift may not have affected their socioeconomic status. The absence of a mortality effect operating through socioeconomic pathways is consistent with the lack of a mediating association between own socioeconomic status and in utero exposure to the Dutch Hunger Winter on later mortality (Ekamper et al., 2014). In contrast, the 1918 Influenza Pandemic and the Chinese Famine affected educational attainment of children in utero during these events (Almond, 2006; Almond et al., 2010). Differential effects of malnutrition and viral illnesses or differences in exposure duration and in sample size (e.g., increased schizophrenia rates may not be noticed in smaller samples) may explain the contrasting impact of these experiences. 
What treatment or treatments does ex-POW status represent? My comparison between non-POWs and exchange ex-POWs male-line grandsons suggests that it is not the psychological trauma of captivity per se which is harmful; but, I cannot unpack starvation from the psychological trauma of starvation. I also cannot observe post-captivity responses to starvation. Post-captivity overfeeding, whether as a biological or psychological response, or overfeeding relative to a starvation norm established during the late growing years, could have triggered an epigenetic response which affected ex-POWs'sons and grandsons.

\section{Conclusion}

Economists have incorporated insights from biology to understand health and socioeconomic outcomes, whether in genome-wide association studies, e.g., Barth et al. (2020), or in analyses of the in-utero origins of disease and disability, e.g., Almond (2006) and Currie and Rossin-Slater (2013). Although epigenetic processes remain a "black box," my findings showed that paternal ancestral conditions can be at least as important as in-utero factors or childhood socioeconomic status in determining the longevity outcomes of older men.

That the bad luck of young men even before they have conceived a child reveberates to their male-line grandsons raises the issues of how to avoid the initial misfortune. For much of human history, ancestral bad luck involved poor harvests and one of the achievements in developing countries has been both to increase the mean of food production and reduce the variance in food consumption through new agricultural techniques, new crops and crop diversification, insurance, and the integration of markets through improvements in 
transportation. Nonetheless, famines still occur in Africa and WWII was accompanied by hunger in Europe and famine in India. The big ancestral misfortune in the US has been slavery. Slaves had a dreadful childhood and were severely malnourished from the womb until field hand age, when such large quantities of protein were introduced into their diets that they experienced remarkable catch-up growth (Steckel, 1986a,b). The unanswered question is how this peculiar nutritional experience affected the health of their descendants.

Ancestral misfortune can take the form of poor choices prior to children's conception, including excessive alcohol consumption, drug use, and smoking. Alterations have been observed in the sperm of adult men as a result of the environment, including age, diet, smoking, alcohol, and exposure to various toxins (Murphy et al., 2016; Nätt et al., 2019). Epigenetics allows not just for the biological transmission of the effects of bad health habits but also for the reversibility of ancestral sins through own health decisions (Dolinoy et al., 2007; Bernal et al., 2013). Noncognitive skills play a role in the formation of good health habits (Conti et al., 2016; Heckman, 2007), suggesting that absent exogenous environmental shocks cultural and epigenetic transmission can be complementary. Although epigenetics has not yet been incorporated into health models (Durlauf, 2018), a potential starting point would be a dynastic model linking health habits across generations through both cultural and epigenetic pathways. 


\section{References}

Almond, Douglas (2006) "Is the 1918 influenza pandemic over? Long-term effects of in utero influenza exposure in the post-1940 US population," Journal of Political Economy, 114 (4), 672-712.

Almond, Douglas, Lena Edlund, Hongbin Li, Junsen Zhang, and Niyogi (2010) "LongTerm Effects of Early-Life Development: Evidence from the 1959 to 1961 China Famine," in Takatoshi, Ito and Andrew Rose eds. The Economic Consequences of Demographic Change in East-Asia, NBER-EASE Volume 19, 321-45, Chicago: University of Chicago Press.

Alsan, Marcella and Claudia Goldin (2019) "Watersheds in Child Mortality: The Role of Effective Water and Sewerage Infrastructure, 1880-1920,' Journal of Political Economy, 127 (2), 586-638.

Barker, DJP (1992) Fetal and Infant Origins of Adult Disease, London: British Medical Publishing Group.

(1994) Mothers, Babies, and Disease in Later Life, London: British Medical Publishing Group.

Barth, Daniel, Nicholas W. Papageorge, and Kevin Thom (2020) "Genetic Endowments and Wealth Inequality," Journal of Political Economy, 128 (4), 1474-1522.

Baxter, Faye A. and Amanda J. Drake (2019) "Non-genetic inheritance via the male germline in mammals," Philosophical transactions of the Royal Society of London. Series B, Biological sciences, 374, 20180118.

Bell, Felicitie C and Michael L Miller (2005) "Life Tables for the United States Social Security Area, 1900-2100," in Actuarial Study No. 120. Social Security Administration, Washington DC: SSA Pub No. 11-11536.

Belloco, Rino (2021) "Mediation analysis in Stata: a short look at med4way," https:/www.stata.com/symposiums/biostatistics-and-epidemiology21/slides/Bio21 Bellocco.pdf .

Van den Berg, GJ and PR Pinger (2016) "Transgenerational effects of childhood conditions on third generation health and education outcomes," Economics and Human Biology, 23 (Dec), 219-229. 
Bernal, AJ, DC Dolinoy, D Huang, DA Skaar, C Weinhouse, and RL Jirtle (2013) “Adaptive radiation-induced epigenetic alterations mitigated by antioxidants," FASEB J, 27 (2), 665-71.

Bygren, Lars Olav, G Kaati, and S Edvinsson (2001) "Longevity determined by paternal ancestors' nutrition during their slow growth period," Acta Biotheor, 49 (1), 53-9.

Bygren, Lars Olov (2013) "Intergenerational Health Responses to Adverse and Enriched Environments," Annual Review of Public Health, 34 (1), 49-60.

Bygren, Lars Olov, Petter Tinghöf, John Carstensen, Sören Edvinsson, Gunnar Kaati, Marcus Pembrey, and Michael Sjöström (2014) "Change in paternal grandmothers' early food supply influenced cardiovascular mortality of the female grandchildren," BMC Genomic Data, 15 (12).

Celli, Viviana (2021) "Causal mediation analysis in economics: Objectives, assumptions, models," Journal of Economic Surveys, https /onlinelibrary.wiley.com/doi/abs/10.1111/joes.12452.

Chetty, Raj, Michael Stepner, Sarah Abraham, Shelby Lin, Benjamin Scuderi, Nicolas Turner, Augustin Bergeron, and David Cutler (2017) "The Association Between Income and Life Expectancy in the United States, 2001-2014," Journal of the American Medical Association, 317 (1), 90.

Class, QA, KM Abel, AS Khashan et al. (2014) "Offspring psychopathology following preconception, prenatal and postnatal maternal bereavement stress," Psychol Med, 44 (1), 71-84.

Class, Quetzal A, Paul Lichtenstein, Niklas Långström, and Brian M D’Onofrio (2011) "Timing of prenatal maternal exposure to severe life events and adverse pregnancy outcomes: a population study of 2.6 million pregnancies," Psychosom Med, 73 (3), 234-41.

Conti, Gabriella and James J Heckman (2010) "Understanding the Early Origins of the Education-Health Gradient: A Framework That Can Also Be Applied to Analyze GeneEnvironment Interactions," Perspectives on psychological science : a journal of the Association for Psychological Science, 5 (5), 585-605.

Conti, Gabriella, James J. Heckman, and Rodrigo Pinto (2016) “The Effects of Two Influential Early Childhood Interventions on Health and Healthy Behaviour," The Economic Journal, 126 (596), F28-F65. 
Costa, Dora (2015) "Health and the Economy in the United States from 1750 to the Present," Journal of Economic Literature, 53 (3), 503-70.

Costa, Dora L (2012) "Scarring and mortality selection among Civil War POWs: A longterm mortality, morbidity and socioeconomic follow-Up," Demography, 49 (4), 1185206.

Costa, Dora L, Heather DeSomer, Christopher Roudiez, Sven Wilson, and Noelle Yetter (2017) “Union Army Veterans All Grown Up.," Historical Methods, 50 (2), 79-95.

Costa, Dora L and Matthew E Kahn (2007) "Surviving Andersonville: The benefits of social networks in POW Camps," American Economic Review, 97 (4), 1467-487.

Costa, Dora L., Noelle Yetter, and Heather DeSomer (2018) "Intergenerational transmission of paternal trauma among US Civil War ex-POWs," Proceedings of the National Academy of Sciences, 115 (44), 11215-11220, https//www.pnas.org/content/115/44/11215.

(2020) "Wartime health shocks and the postwar socioeconomic status and mortality of union army veterans and their children," Journal of Health Economics, 70, 102281.

Currie, Janet and Maya Rossin-Slater (2013) "Weathering the Storm: Hurricanes and Birth Outcomes," J Health Econ, 32 (3), 487-503.

Cutler, David, Angus Deaton, and Adriana Llereas-Muney (2006) "The Determinants of Mortality," Journal of Economic Perspectives, 20 (3), 97-120.

Deaton, Angus (2013) The Great Escape; Health, Wealth, and the Origins of Inequality, Princeton, NJ: Princeton University Press.

Doblhammer, G and JW Vaupel (2001) "Lifespan depends in month of birth," Proc Natl Acad Sci USA, 98 (5), 2934-39.

Dolinoy, DC, D Huang, and RL Jirtle (2007) "Maternal nutrient supplementation counteracts bisphenol A-induced DNA hypomethylation in early development," Proc Natl Acad Sci USA, 104 (32), 13056-61.

Durlauf, Steven (2018) "Intergenerational Mobility," https:/hceconomics.uchicago.edu/sites/default/files/file uploads/Durlauf-IM-SSSI\%202018\%20Chicago.pd 
Ekamper, P, F van Poppel, AD Stein, and LH Lumey (2014) "Independent and additive association of prenatal famine exposure and intermediary life conditions with adult mortality age 18-63 years," Soc Sci Med, 119 (Oct), 232-9.

Finkelstein, Amy, Matthew Gentzkow, and Heidi Williams (2021) "Place-Based Drivers of Mortality: Evidence from Migration," American Economic Review, 111 (8), 26972735 .

Floud, Roderick, Robert W. Fogel, Bernard Harris, and Sok Chul Hong (2011) The Changing Body: Health, Nutrition, and Human Development in the Western World since 1700, Cambridge: Cambridge University Press.

Gavrilova, Natalia, Leonid A Gavrilov, Galina N Evdokushkina, and Victoria G Semyonova (2003) "Early-life predictors of human longevity: Analysis of XIXth Century Birth Cohorts," Annales de démographie historique, 106 (2), 177-98.

Heard, Edith and Robert A Martienssen (2014) "Transgenerational epigenetic inheritance: myths and mechanisms," Cell, 157 (1), 95-109.

Heckman, James J. (2007) “The economics, technology, and neuroscience of human capability formation," Proceedings of the National Academy of Sciences, 104 (33), 13250-

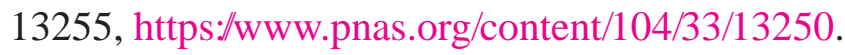

Heijmans, BT, EW Tobi, AD Stein, H Putter, GJ Blauw, ES Susser, PE Slagboom, and LH Lumey (2008) "Persistent epigenetic differences associated with prenatal exposure to famine in humans," Proc Natl Acad Sci USA, 104 (44), 17046-9.

Kaati, Gunnar, Lars Olov Bygren, Marcus Pembrey, and Michael Sjöström (2007) "Transgenerational response to nutrition, early life circumstances and longevity," Eur J Hum Genet, 15 (7), 784-90.

Kambourov, Gueorgui and Iourii Manovskii (2009) "Occupational Specificity of Human Capital,” International Economic Review, 50 (1), 63-115.

Luke, Nancy, Kaivan Munshi, Anu Oomen, and Swapnil Singh (2021) "Economic Development, the Nutrition Trap, and Metabolic Disease," National Bureau of Economic Research Working Paper Series (29132).

Lumey, LH and FWA van Poppel (2013) “The Dutch Famine of 1944-45 as a Human Laboratory: Changes in the Early Life Environment and Adult Health," in Lumey, LH and Alexander Vaiserman eds. Early Life Nutrition and Adult Health and Development, 59-76, Hauppage, New York: Nova Science Publishers. 
Marvel, William (1994) Andersonville: The Last Depot, Chapel Hill, NC and London: The University of North Carolina Press.

Murphy, KE, TG Jenkins, and DT Carrell (2016) "How the Father Might Epigenetically Program the Risk for Developmental Origins of Health and Disease Effects in His Offspring," in Rosenfeld, Cheryl ed. The Epigenome and Developmental Origins of Health and Disease, 361-75, London: Academic Press, Chapter 18.

Nätt, Daniel, Unn Kugelberg, Eduard Casas et al. (2019) "Human sperm displays rapid responses to diet," PLOS Biology, 17 (12), 1-25, https:/doi.org/10.1371/journal.pbio.3000559.

Neal, Derrick (1995) "Industry-Specific Human Capital: Evidence from Displaced Workers," Journal of Labor Economics, 13 (4), 653-77.

stbye and Taylor

Østbye, Truls and Donald H Taylor (2004) “The effect of smoking on years of healthy life (YHL) lost among middle-aged and older Americans," Health Services Research, 39 (3), 531-52.

Parent, Daniel (2000) "Industry-Specific Capital and the Wage Profile: Evidence from the National Longitudinal Survey of Youth and the Panel Study of Income Dynamics," Journal of Labor Economics, 18 (2), 306-23.

Persson, P and M Rossin-Slater (2018) "Family Ruptures, Stress, and the Mental Health of the Next Generation," American Economic Review, 108 (4-5), 1214-52.

Rosenquist, James Niels, Steven F. Lehrer, A. James O’Malley, Alan M. Zaslavsky, Jordan W. Smoller, and Nicholas A. Christakis (2015) "Cohort of birth modifies the association between FTO genotype and BMI," Proceedings of the National Academy of Sciences, 112 (2), 354-359, https:/www.pnas.org/content/112/2/354.

Steckel, Richard H. (1986a) "A Dreadful Childhood: The Excess Mortality of American Slaves," Social Science History, 10 (4), 427-465.

(1986b) "A Peculiar Population: The Nutrition, Health, and Mortality of American Slaves from Childhood to Maturity," The Journal of Economic History, 46 (3), 721-741.

Veenendaal, MV, RC Painter, SR de Rooij, PM Bossuyt, JA van der Post, PD Gluckman, MA Hanson, and TJ Roseboom (2013) "Transgenerational effects of prenatal exposure to the 1944-45 Dutch famine," BJOG, 120 (5), 548-53. 
Vågerö, Denny, Pia R Pinger, Vanda Aronsson, and Gerard J. van den Berg (2018) "Paternal grandfather's access to food predicts all-cause and cancer mortality in grandsons," Nature Communications, 9 (5124).

(2021) "Author Correction: Paternal grandfather's access to food predicts allcause and cancer mortality in grandsons," Nature Communications, 12 (1954).

Wilson, Sven E and Clayne L Pope (2003) "The Height of Union Army Recruits," in Costa, Dora L ed. Health and Labor Force Participation Over the Life Cycle, 113-145, Chicago: University of Chicago Press. 
Table 1: Mean Characteristics of Veterans by Ex-POW Status

\begin{tabular}{|c|c|c|c|}
\hline Veteran characteristics & Non-POW & $\begin{array}{l}\text { Exchange } \\
\text { Ex-POW }\end{array}$ & $\begin{array}{l}\text { Non- } \\
\text { Exchange } \\
\text { Ex-POW }\end{array}$ \\
\hline Born in the US & 0.86 & 0.84 & 0.85 \\
\hline Enlisted in a city of $50,000+$ & 0.03 & 0.04 & 0.04 \\
\hline Wounded & 0.32 & 0.33 & 0.32 \\
\hline \multicolumn{4}{|l|}{ Enlistment occupation } \\
\hline Farmer & 0.71 & 0.69 & 0.62 \\
\hline Professional/proprietor & 0.03 & 0.03 & 0.03 \\
\hline Artisan & 0.11 & 0.12 & 0.13 \\
\hline Laborer & 0.15 & 0.14 & 0.21 \\
\hline Unknown & 0.01 & 0.03 & 0.03 \\
\hline \multicolumn{4}{|l|}{ Enlistment year } \\
\hline 1861 & 0.33 & 0.43 & 0.44 \\
\hline 1862 & 0.38 & 0.38 & 0.43 \\
\hline 1863 & 0.08 & 0.06 & 0.07 \\
\hline 1864 & 0.21 & 0.12 & 0.06 \\
\hline 1865 & 0.00 & 0.01 & 0.00 \\
\hline \multicolumn{4}{|l|}{ Occupation in 1880} \\
\hline Farmer & 0.56 & 0.61 & 0.50 \\
\hline Professional/proprietor & 0.05 & 0.06 & 0.06 \\
\hline Artisan & 0.09 & 0.09 & 0.14 \\
\hline Farmer laborer & 0.03 & 0.03 & 0.03 \\
\hline Laborer & 0.20 & 0.17 & 0.22 \\
\hline No occupation & 0.03 & 0.01 & 0.01 \\
\hline Not in census & 0.04 & 0.03 & 0.03 \\
\hline Years lived (conditional on living to 1900 ) & 75.37 & 77.17 & 74.42 \\
\hline
\end{tabular}

Mean characteristics are for veterans in the analytical sample, that is, all veterans with a grandchild who lived to age 45 and who descended from the child of a veteran born after the war. 
Table 2: Mean Characteristics of Veterans' Grandchildren Surviving to Age 45 by Veteran's Ex-POW Status

\begin{tabular}{|c|c|c|c|}
\hline Grandchildrens' characteristics & Non-POW & $\begin{array}{l}\text { Exchange } \\
\text { Ex-POW }\end{array}$ & $\begin{array}{l}\text { Non- } \\
\text { Exchange } \\
\text { Ex-POW }\end{array}$ \\
\hline Birth Year & 1907.41 & 1907.80 & 1907.26 \\
\hline \multicolumn{4}{|l|}{ Father was veteran's son and was } \\
\hline ever a laborer & 0.26 & 0.25 & 0.26 \\
\hline ever a farmer & 0.27 & 0.25 & 0.21 \\
\hline never a home owner & 0.62 & 0.65 & 0.68 \\
\hline \multicolumn{4}{|l|}{ Father was veteran's son-in-law and was } \\
\hline ever a laborer & 0.18 & 0.19 & 0.19 \\
\hline ever a farmer & 0.24 & 0.24 & 0.24 \\
\hline never a home owner & 0.67 & 0.65 & 0.64 \\
\hline Number of siblings & 4.37 & 4.37 & 4.41 \\
\hline Veteran living in the same county & 0.34 & 0.35 & 0.32 \\
\hline Veteran living in the same household & 0.03 & 0.05 & 0.04 \\
\hline Years lived & 76.40 & 76.13 & 76.10 \\
\hline \multicolumn{4}{|l|}{$\begin{array}{l}\text { Years lived by } \\
\text { parent who lived to age } 45 \text { and wa }\end{array}$} \\
\hline veteran’s son & 73.58 & 73.61 & 72.56 \\
\hline veteran's son-in-law & 73.94 & 73.15 & 74.29 \\
\hline veteran's daughter & 75.89 & 75.97 & 75.90 \\
\hline veteran's daughter-in-law & 76.51 & 76.14 & 77.04 \\
\hline
\end{tabular}

Mean characteristics are for veterans' granchildren in the analytical sample, that is, all grandchildren who survived to age 45 and were children born after the war to a veteran. 
Table 3: Granchildren's Mean Years Lived by Ancestral Line and Grandfather's Ex-POW Status

\begin{tabular}{|c|c|c|c|c|}
\hline \multirow[b]{2}{*}{$\begin{array}{l}\text { Grandfather's } \\
\text { Ex-POW status }\end{array}$} & \multicolumn{2}{|c|}{ Male-line } & \multicolumn{2}{|c|}{ Female-line } \\
\hline & $\begin{array}{l}\text { Grand- } \\
\text { sons }\end{array}$ & $\begin{array}{l}\text { Grand- } \\
\text { daughters }\end{array}$ & $\begin{array}{l}\text { Grand- } \\
\text { sons }\end{array}$ & $\begin{array}{l}\text { Grand- } \\
\text { daughters }\end{array}$ \\
\hline \multicolumn{5}{|c|}{ Mean Years Lived } \\
\hline Non-POW & 73.79 & 79.64 & 73.13 & 79.53 \\
\hline Exchange Ex-POW & 73.60 & 79.78 & 72.62 & 79.27 \\
\hline Non-exchange Ex-POW & 72.74 & 79.41 & 73.34 & 79.40 \\
\hline \multicolumn{5}{|c|}{ Propensity Score Adjusted Mean Years Lived } \\
\hline Non-exchange Ex-POW & 72.444 & 79.404 & 73.334 & 79.405 \\
\hline Non-POW & 73.802 & 79.749 & 72.985 & 79.410 \\
\hline \multirow[t]{3}{*}{ ATT } & $-1.059 * * *$ & -0.344 & 0.349 & -0.005 \\
\hline & (0.394) & $(0.413)$ & $(0.391)$ & $(0.429)$ \\
\hline & [0.007] & [0.404] & [0.371] & [0.992] \\
\hline \multirow[t]{3}{*}{ ATE } & $-0.839 * *$ & -0.107 & 0.397 & -0.075 \\
\hline & $(0.415)$ & $(0.442)$ & $(0.387)$ & $(0.428)$ \\
\hline & [0.043] & [0.809] & [0.306] & [0.862] \\
\hline Non-exchange Ex-POW & 72.756 & 79.404 & 73.334 & 79.403 \\
\hline Exchange Ex-POW & 73.435 & 79.654 & 72.635 & 79.378 \\
\hline \multirow[t]{3}{*}{ ATT } & -0.678 & -0.250 & 0.699 & 0.025 \\
\hline & $(0.462)$ & $(0.477)$ & $(0.454)$ & $(0.498)$ \\
\hline & {$[0.142]$} & {$[0.600]$} & {$[0.124]$} & {$[0.960]$} \\
\hline \multirow[t]{3}{*}{ ATE } & -0.658 & -0.260 & $0.826^{*}$ & 0.147 \\
\hline & $(0.458)$ & $(0.466)$ & $(0.439)$ & $(0.481)$ \\
\hline & {$[0.151]$} & [0.577] & {$[0.060]$} & {$[0.759]$} \\
\hline
\end{tabular}

Years lived are for grandchildren who lived to age 45 and who were descended from the child of a veteran born after the war. Matching used a probit, common support and an Epanechnikov kernel and used only the veteran's pre-enlistment characteristics: dummmies for enlistment year, occupation at enlistment (farmer, artisan, laborer, professional or proprietor, and unknown), enlistment in a city with population of 50,000 or more, born in the US, and wounded in the war. Bootstrap standard errors (1,000 replications) are in parentheses. P-valuses are in square brackets. 
Table 4: Hazard Ratios of Mortality by Grandfather's Ex-POW Status

\begin{tabular}{lcccc}
\hline \multirow{2}{*}{$\begin{array}{l}\text { Grandfather's } \\
\text { ex-POW status }\end{array}$} & $\begin{array}{c}\text { Mrand- } \\
\text { sons }\end{array}$ & $\begin{array}{c}\text { Grand- } \\
\text { daughters }\end{array}$ & $\begin{array}{c}\text { Grand- } \\
\text { sons }\end{array}$ & $\begin{array}{c}\text { Grand- } \\
\text { daughters }\end{array}$ \\
\cline { 2 - 5 } Non-POW & 1.000 & 1.000 & 1.000 & 1.000 \\
Exchange Ex-POW & 1.029 & 1.027 & $1.065 *$ & 1.021 \\
& $(0.040)$ & $(0.042)$ & $(0.041)$ & $(0.042)$ \\
& {$[0.459]$} & {$[0.517]$} & {$[0.099]$} & {$[0.614]$} \\
Non-exchange Ex-POW & $1.113 * *$ & 1.022 & 0.997 & 0.995 \\
& $(0.046)$ & $(0.045)$ & $(0.042)$ & $(0.041)$ \\
& {$[0.011]$} & {$[0.621]$} & {$[0.934]$} & {$[0.910]$} \\
Non-exchange Ex-POW & & & & \\
relative to Exchange Ex-POW & $1.081 * *$ & 0.995 & 0.935 & 0.975 \\
& $(0.043)$ & $(0.042)$ & $(0.038)$ & $(0.039)$ \\
& {$[0.049]$} & {$[0.915]$} & {$[0.102]$} & {$[0.531]$} \\
Test of proportional hazards & 15.12 & 17.71 & 15.36 & 13.11 \\
$\quad$ assumption, $\chi^{2}$, Pr $>\chi^{2}(15)$ & {$[0.4425]$} & {$[0.278]$} & {$[0.426]$} & {$[0.594]$} \\
Observations & 6,685 & 6,055 & 6,140 & 5,644 \\
\hline
\end{tabular}

Estimated from a Cox proportional hazards model using years lived after age 45, stratifying on birth cohort, and controlling for birth year and the veteran's enlistment year, occupation at enlistment (farmer, artisan, laborer, professional or proprietor, and unknown), enlistment in a city with population of 50,000 or more, born in the US, wounded in the war, and in the original Union Army sample. Standard errors, clustered on the veteran are in parenthesis. P values are in square brackets. The proportional hazards assumption is tested using the Schoenfeld residuals. The symbols *,**, and $* * *$ indicate significance at the 10,5 , and 1 percent level. 
Table 5: Hazard Ratios of Mortality by Grandfather's Ex-POW Status, Pooled by Sex Sample

\begin{tabular}{|c|c|c|c|c|}
\hline \multirow[b]{2}{*}{ Grandfather was } & \multicolumn{2}{|c|}{ Grandsons } & \multicolumn{2}{|c|}{ Granddaughters } \\
\hline & $\begin{array}{l}\text { Male- } \\
\text { line }\end{array}$ & $\begin{array}{l}\text { Female- } \\
\text { line }\end{array}$ & $\begin{array}{l}\text { Male- } \\
\text { line }\end{array}$ & $\begin{array}{l}\text { Female- } \\
\text { line }\end{array}$ \\
\hline Non-POW & 1.000 & 1.000 & 1.000 & 1.000 \\
\hline Exchange Ex-POW & $\begin{array}{l}1.036 \\
(0.038) \\
{[0.3271}\end{array}$ & $\begin{array}{l}1.053 \\
(0.039) \\
{[0.167]}\end{array}$ & $\begin{array}{l}1.020 \\
(0.038) \\
{[0.590]}\end{array}$ & $\begin{array}{l}1.028 \\
(0.040) \\
{[0.482]}\end{array}$ \\
\hline Non-exchange Ex-POW & $\begin{array}{l}1.114 * * * \\
(0.043) \\
{[0.005]}\end{array}$ & $\begin{array}{c}0.991 \\
(0.040) \\
{[0.829]}\end{array}$ & $\begin{array}{l}1.015 \\
(0.041) \\
{[0.721]}\end{array}$ & $\begin{array}{l}1.008 \\
(0.039) \\
{[0.840]}\end{array}$ \\
\hline $\begin{array}{l}\text { Non-exchange Ex-POW } \\
\text { relative to Exchange Ex-POW }\end{array}$ & $\begin{array}{l}1.075^{*} \\
(0.042) \\
{[0.066]}\end{array}$ & $\begin{array}{c}0.942 \\
(0.039) \\
{[0.150]}\end{array}$ & $\begin{array}{c}0.995 \\
(0.041) \\
{[0.896]}\end{array}$ & $\begin{array}{c}0.981 \\
(0.040) \\
{[0.633]}\end{array}$ \\
\hline $\begin{array}{l}D_{P O W=N}: \text { Male-line Non-exchange Ex-POW } \\
\quad \text { relative to Female-line Non-exchange Ex-POW }\end{array}$ & $\begin{array}{l}1.078^{*} \\
(0.042) \\
{[0.055]}\end{array}$ & & $\begin{array}{l}1.006 \\
(0.042) \\
{[0.880]}\end{array}$ & \\
\hline $\begin{array}{l}D_{P O W=E}: \text { Male-line Exchange Ex-POW } \\
\quad \text { relative to Female-line Exchange Ex-POW }\end{array}$ & $\begin{array}{c}0.944 \\
(0.034) \\
{[0.108]}\end{array}$ & & $\begin{array}{l}0.993 \\
(0.038) \\
{[0.843]}\end{array}$ & \\
\hline $\begin{array}{l}D_{P O W=0}: \text { Male-line Non-POW } \\
\quad \text { relative to Female-line Non-POW }\end{array}$ & $\begin{array}{l}0.959 \\
(0.026) \\
{[0.119]}\end{array}$ & & $\begin{array}{l}1.000 \\
(0.029) \\
{[0.482]}\end{array}$ & \\
\hline$D_{P O W}=N-D_{P O W}=0$ & $\begin{array}{l}1.123 * * \\
(0.053) \\
{[0.013]}\end{array}$ & & $\begin{array}{l}1.007 \\
(0.052) \\
{[0.897]}\end{array}$ & \\
\hline$D_{P O W=N}-D_{P O W=E}$ & $\begin{array}{l}1.141 * * \\
(0.059) \\
{[0.012]}\end{array}$ & & $\begin{array}{l}1.014 \\
(0.058) \\
{[0.807]}\end{array}$ & \\
\hline $\begin{array}{l}\text { Test of proportional hazards } \\
\text { assumption, } \chi^{2}, \operatorname{Pr}>\chi^{2}(17) \\
\text { Observations }\end{array}$ & $\begin{array}{l}17 \\
{[0.4} \\
12\end{array}$ & & $\begin{array}{r}2 \\
{[0 .} \\
11\end{array}$ & $\begin{array}{l}41 \\
09] \\
699\end{array}$ \\
\hline
\end{tabular}

Estimated from a Cox proportional hazards model on the sample pooled by sex using years lived after age 45, stratifying on birth cohort, and controlling for birth year and the veteran's enlistment year, occupation at enlistment (farmer, artisan, laborer, professional or proprietor, and unknown), enlistment in a city with population of 50,000 or more, born in the US, wounded in the war, and in the original Union Army sample. Standard errors, and stratifying on birth cohort. Standard errors, clustered on the veteran are in parenthesis. P values are in square brackets. The proportional hazards assumption is tested using the Schoenfeld resigduals. The symbols *, **, and *** indicate significance at the 10,5 , and 1 percent level. 
Table 6: Hazard Ratios of Mortality by Grandfather's Ex-POW Status, Controlling for Post-War Variables

\begin{tabular}{ccccc}
\hline & \multicolumn{2}{c}{ Male-line } & \multicolumn{2}{c}{ Female-line } \\
\cline { 2 - 5 } & $\begin{array}{c}\text { Grand- } \\
\text { sons }\end{array}$ & $\begin{array}{c}\text { Grand- } \\
\text { daughters }\end{array}$ & $\begin{array}{c}\text { Grand- } \\
\text { sons }\end{array}$ & $\begin{array}{c}\text { Grand- } \\
\text { daughters }\end{array}$ \\
\hline Grandfather was & & & & \\
Non-POW & 1.000 & 1.000 & 1.000 & 1.000 \\
Exchange Ex-POW & 1.031 & 1.035 & 1.059 & 1.013 \\
& $(0.038)$ & $(0.042)$ & $(0.040)$ & $(0.041)$ \\
Non-exchange Ex-POW & {$[0.403]$} & {$[0.386]$} & {$[0.128]$} & {$[0.756]$} \\
& $1.104 * *$ & 1.025 & 1.003 & 1.001 \\
& $(0.045)$ & $(0.044)$ & $(0.042)$ & $(0.041)$ \\
Grandchild's Father was & {$[0.014]$} & {$[0.572]$} & {$[0.951]$} & {$[0.979]$} \\
a laborer at any time & & & & \\
& $1.083 * * *$ & $1.078 * * *$ & $1.162 * * *$ & $1.137 * * *$ \\
a farmer at any time & $(0.031)$ & $(0.030)$ & $(0.035)$ & $(0.035)$ \\
& {$[0.005]$} & {$[0.007]$} & {$[0.000]$} & {$[0.000]$} \\
never a home owner & $0.923 * * *$ & $0.885 * * *$ & $0.909 * * *$ & 0.965 \\
Observations & $(0.028)$ & $(0.028)$ & $(0.030)$ & $(0.032)$ \\
& {$[0.009]$} & {$[0.000]$} & {$[0.003]$} & {$[0.276]$} \\
& $1.122^{* * *}$ & 1.017 & $1.111 * * *$ & $1.088 * * *$ \\
Test of proportional hazards & $(0.032)$ & $(0.032)$ & $(0.034)$ & $(0.033)$ \\
Non-exchange Ex-POW & {$[0.000]$} & {$[0.583]$} & {$[0.001]$} & {$[0.006]$} \\
relative to Exchange Ex-POW & $1.070 *$ & 0.999 & 0.947 & 0.988 \\
& $(0.041)$ & $(0.041)$ & $(0.038)$ & $(0.040)$ \\
& {$[0.077]$} & {$[0.803]$} & {$[0.178]$} & {$[0.775]$} \\
& 35.11 & 34.91 & 30.99 & 25.25 \\
& {$[0.136]$} & {$[0.141]$} & {$[0.272]$} & {$[0.560]$} \\
& 6,685 & 6,055 & 6,140 & 5,644 \\
\hline
\end{tabular}

Estimated from a Cox proportional hazards model on the sample pooled by sex using years lived after age 45 and stratifying on birth cohort and census region of birth. Controls are for birth year; for the veteran's enlistment year, occupation at enlistment (farmer, artisan, laborer, professional or proprietor, and unknown), enlistment in a city with population of 50,000 or more, birth in the US, whether wounded in the war, whether in the original Union Army sample, 1880 occupation (farmer, artisan, laborer, professional or proprietor, not in the labor force, and not in the census), and whether a home owner; and whether the veteran was ever in the same county as the grandchild, was ever in the same household as the grandchild, and the total number of siblings in the family. Standard errors, clustered on the veteran, are in parentheses. P values are in square brackets. The proportional hazards assumption is tested using the Schoenfeld residuals. The symbols $*, * *$, and $* * *$ indicate significance at the 10,5 , and 1 percent level. 
Table 7: Grandchildren's Hazard Ratios of Mortality by Grandfather's Ex-POW Status Conditional on Grandfather at Risk of Being a No-Exchange Ex-POW at Ages 17 to 24

\begin{tabular}{lcccc}
\hline \multirow{2}{*}{$\begin{array}{l}\text { Grandfather's } \\
\text { ex-POW status }\end{array}$} & $\begin{array}{c}\text { Grand- } \\
\text { sons }\end{array}$ & $\begin{array}{c}\text { Grand- } \\
\text { daughters }\end{array}$ & $\begin{array}{c}\text { Grand- } \\
\text { sons }\end{array}$ & $\begin{array}{c}\text { Grand- } \\
\text { daughters }\end{array}$ \\
\cline { 2 - 5 } Non-POW & 1.000 & 1.000 & 1.000 & 1.000 \\
Exchange Ex-POW & & & & \\
& $1.108 * *$ & 1.032 & 1.063 & 1.034 \\
& $(0.050)$ & $(0.051)$ & $(0.050)$ & $(0.052)$ \\
Non-exchange Ex-POW & {$[0.024]$} & {$[0.526]$} & {$[0.196]$} & {$[0.503]$} \\
& $1.218 * * *$ & 1.058 & 0.964 & 1.010 \\
Non-exchange Ex-POW & $(0.060)$ & $(0.057)$ & $(0.046)$ & $(0.049)$ \\
relative to Exchange Ex-POW & {$[0.000]$} & {$[0.296]$} & {$[0.446]$} & {$[0.837]$} \\
& $1.099 * *$ & 1.025 & 0.907 & 0.977 \\
& $(0.049)$ & $(0.051)$ & $(0.043)$ & $(0.047)$ \\
Test of proportional hazards & {$[0.035]$} & {$[0.615]$} & {$[0.041]$} & {$[0.622]$} \\
$\quad$ assumption, $\chi^{2}$, Pr $>\chi^{2}$ & 15.46 & 16.66 & 18.93 & 20.01 \\
Observations & {$[0.419]$} & {$[0.339]$} & {$[0.217]$} & {$[0.172]$} \\
\hline
\end{tabular}

The sample has been restricted to grandchildren whose grandfathers were age 17-24 when at risk of being a noexchange ex-POW. Estimated from a Cox proportional hazards model using years lived after age 45, stratifying on birth cohort, and controlling for birth year and the veteran's enlistment year, occupation at enlistment (farmer, artisan, laborer, professional or proprietor, and unknown), enlistment in a city with population of 50,000 or more, born in the US, wounded in the war, and in the original Union Army sample. Standard errors, clustered on the veteran, are in parentheses. P values are in square brackets. The proportional hazards assumption is tested using the Schoenfeld residuals. The symbols *,**, and *** indicate significance at the 10,5, and 1 percent level. 
Table 8: Male-line Grandson's Hazard Ratios of Mortality after Age 45 by Grandfather's Ex-POW Status and Grandson's Quarter of Birth

\begin{tabular}{|c|c|c|c|c|}
\hline & \multicolumn{4}{|c|}{ Male-line Grandson was born in quarter } \\
\hline & 1 & 2 & 3 & 4 \\
\hline \multicolumn{5}{|l|}{ Grandfather was } \\
\hline Non-POW & 1.000 & 1.000 & 1.000 & 1.000 \\
\hline \multirow[t]{3}{*}{ Exchange Ex-POW } & 1.046 & 1.081 & 1.028 & 0.975 \\
\hline & $(0.065)$ & $(0.070)$ & $(0.059)$ & $(0.064)$ \\
\hline & {$[0.468]$} & {$[0.231]$} & {$[0.628]$} & [0.700] \\
\hline \multirow[t]{3}{*}{ Non-exchange Ex-POW } & $1.168 * *$ & $1.152 * *$ & 1.055 & 1.102 \\
\hline & $(0.080)$ & $(0.077)$ & $(0.063)$ & $(0.071)$ \\
\hline & {$[0.025]$} & {$[0.035]$} & {$[0.379]$} & {$[0.131]$} \\
\hline \multirow{3}{*}{$\begin{array}{l}\text { Non-exchange Ex-POW } \\
\text { relative to Exchange Ex-POW }\end{array}$} & 1.117 & 1.1066 & 1.026 & $1.131 *$ \\
\hline & $(0.081)$ & $(0.078)$ & $(0.063)$ & $(0.082)$ \\
\hline & {$[0.126]$} & {$[0.385]$} & {$[0.677]$} & [0.088] \\
\hline
\end{tabular}

6,545 observations. Estimates are from Equation 3 and the odds ratios were expressed to allow for easy comparisons across grandfather's ex-POW status within the grandson's quarter of birth. The test of the proportional hazards assumption using the Schoenfeld residuals yielded a $\chi^{2}$ of 26.74 with 25 degrees of freedom and a value of 0.336 . Control variables include birth year and the veteran's enlistment year, occupation at enlistment (farmer, artisan, laborer, professional or proprietor, and unknown), enlistment in a city with population of 50,000 or more, born in the US, wounded in the war, and in the original Union Army sample. Standard errors, clustered on the veteran, are in parentheses. $\mathrm{P}$ values are in square brackets. The symbols *, **, and *** indicate significance at the 10,5 , and 1 percent level. 
Table 9: Sons' and Male-Line Grandchildren's Hazard Ratios of Mortality by Veteran's Ex-POW Status

\begin{tabular}{lcccc}
\hline & $\begin{array}{c}\text { Father of } \\
\text { Grand- } \\
\text { son }\end{array}$ & $\begin{array}{c}\text { Grand- } \\
\text { son }\end{array}$ & $\begin{array}{c}\text { Father of } \\
\text { Grand- } \\
\text { daughter }\end{array}$ & $\begin{array}{c}\text { Grand- } \\
\text { daughter }\end{array}$ \\
\hline Father/Grandfather was & 1.000 & 1.000 & 1.000 & 1.000 \\
Non-POW & & & & \\
Exchange Ex-POW & 1.064 & 1.016 & 1.072 & 1.016 \\
& $(0.054)$ & $(0.040)$ & $(0.058)$ & $(0.042)$ \\
& {$[0.222]$} & {$[0.682]$} & {$[0.200]$} & {$[0.694]$} \\
Non-exchange Ex-POW & $1.165 * *$ & $1.101 * *$ & $1.150 * *$ & 1.033 \\
& $(0.072)$ & $(0.047)$ & $(0.071)$ & $(0.046)$ \\
Non-exchange Ex-POW & {$[0.014]$} & {$[0.024]$} & {$[0.023]$} & {$[0.475]$} \\
relative to Exchange Ex-POW & $1.095^{*}$ & $1.083 *$ & 1.073 & 1.016 \\
& $(0.060)$ & $(0.044)$ & $(0.060)$ & $(0.043)$ \\
& {$[0.099]$} & {$[0.048]$} & {$[0.205]$} & {$[0.709]$} \\
Test of proportional hazards & 16.92 & 14.56 & 5.14 & 16.80 \\
$\quad$ assumption, $\chi^{2}$, Pr $>\chi^{2}$ & {$[0.324]$} & {$[0.483]$} & {$[0.991]$} & {$[0.331]$} \\
& & & & \\
Observations & 3,175 & 6,434 & 2,959 & 5,812 \\
\hline
\end{tabular}

The sample is restricted to all grandchildren who survived to age 45 and who had a father who was a veteran's son and who survived to age 45. Estimated from a Cox proportional hazards model using years lived after age 45, stratifying on birth cohort, and controlling for birth year and the veteran's enlistment year, occupation at enlistment (farmer, artisan, laborer, professional or proprietor, and unknown), enlistment in a city with population of 50,000 or more, born in the US, wounded in the war, and in the original Union Army sample. Standard errors, clustered on the veteran, are in parentheses. P values are in square brackets. The proportional hazards assumption is tested using the Schoenfeld residuals. The symbols $*, * *$, and $* * *$ indicate significance at the 10,5 , and 1 percent level. 
Table 10: Excess Risk in Male Line Grandsons' Mortality After Age 45, by Grandfather's Ex-Pow Status and as Mediated by Paternal Longevity

\begin{tabular}{|c|c|c|c|c|c|c|}
\hline \multirow[t]{2}{*}{ Grandfathers: } & \multicolumn{3}{|c|}{ All } & \multicolumn{3}{|c|}{ At Risk at Ages 17-24 } \\
\hline & $\begin{array}{l}\text { Coeff- } \\
\text { icient- }\end{array}$ & $\begin{array}{l}\text { Std. } \\
\text { Err. }\end{array}$ & $\begin{array}{c}\text { P- } \\
\text { Value }\end{array}$ & $\begin{array}{l}\text { Coeff- } \\
\text { icient- }\end{array}$ & $\begin{array}{l}\text { Std. } \\
\text { Err. }\end{array}$ & $\begin{array}{c}\text { P- } \\
\text { Value }\end{array}$ \\
\hline \multicolumn{7}{|c|}{ Grandfather was non-exchange ex-POW relative to exchange ex-POW } \\
\hline Observations: & 4,550 & & & 2,707 & & \\
\hline Total effect & $0.100 * *$ & 0.049 & 0.041 & $0.169 * * *$ & 0.062 & 0.007 \\
\hline Controlled direct effect & $0.083^{*}$ & 0.049 & 0.086 & $0.160 * * *$ & 0.062 & 0.010 \\
\hline Interaction only & 0.000 & 0.001 & 0.445 & -0.002 & 0.002 & 0.361 \\
\hline Mediated interaction & -0.002 & 0.008 & 0.778 & -0.007 & 0.009 & 0.419 \\
\hline Pure indirect effect & $0.020 * * *$ & 0.005 & 0.000 & $0.017 * * *$ & 0.006 & 0.009 \\
\hline
\end{tabular}

Total effect due to indirect effect and mediated interaction:

$$
\begin{array}{cc}
((0.020-0.002) / 0.100) & ((0.017-0.007) / 0.169) \\
=18 \% & =6 \%
\end{array}
$$

Grandfather was non-exchange ex-POW relative to exchange ex-POW

$\begin{array}{lcccccc}\text { Observations: } & 2,828 & & & 2,017 \\ \text { Total effect } & 0.069 * & 0.041 & 0.094 & 0.070 & 0.049 & 0.149 \\ \text { Controlled direct effect } & 0.060 & 0.041 & 0.140 & 0.065 & 0.048 & 0.178 \\ \text { Interaction only } & -0.001 & 0.002 & 0.588 & -0.002 & 0.003 & 0.493 \\ \text { Mediated interaction } & -0.002 & 0.005 & 0.646 & -0.005 & 0.006 & 0.481 \\ \text { Pure indirect effect } & 0.012 * * & 0.005 & 0.011 & 0.011 * * & 0.006 & 0.041\end{array}$

Total effect due to indirect effect and mediated interaction:

$$
\begin{aligned}
& ((0.012-0.002) / 0.069) \quad((0.011-0.005) / 0.070) \\
& =14 \%=9 \%
\end{aligned}
$$

At risk = at risk of being a non-exchange ex-POW. Results are from two mediation analyses on two samples where the first contains only non-exchange ex-POWs and non-POWs and the second contains only non-exchange and exchange ex-POWs. A Cox proportional hazards model was used to estimate the survival equation and a linear equation was used to estimate paternal survival. Control variables include the veteran's enlistment year, occupation at enlistment (farmer, artisan, laborer, professional or proprietor, and unknown), enlistment in a city with population of 50,000 or more, born in the US, wounded in the war, and in the original Union Army sample. The values of control variables and of the mediating variable (father's years lived) were set to mean values. 


\section{Appendix A: Sample Construction}

Figure A1 provides a schematic showing sample construction. I study the grandchildren of veterans drawn from two different longitudinal samples constructed from hand written military service and pension records (including detailed examining surgeons' exams), preserved in the National Archives, and from manuscript census schedules. The first sample is of 39,388 men in 330 randomly drawn Union Army volunteer infantry companies, collected by the program project, Early Indicators of Later Work Levels, Disease, and Death (NIA P01 AG10120, PI: Fogel). This sample is representative of the Northern population of military age in 1860 in terms of socioeconomic status (Fogel 1993) and will be referred to as the original Union Army sample. I restricted this sample to men who survived to 1900. The second sample, collected by the project Environmental Stress, Social Networks, and Older Age Health and Mortality (NIA R01 AG027960, PI: Costa), is of 1,041 ex-POWs imprisoned at the most notorious Confederate POW camp, Andersonville, and who survived until 1900. The men were randomly drawn from a list of Andersonville prisoners of war compiled by the National Park Service and will be referred to as the Andersonville sample.

A subsample of veterans' children has been linked to death records and manuscript census schedules which provide occupational, residential, and family information under the program project Early Indicators, Intergenerational Processes, and Aging (NIA P01 AG10120, PI: Costa). Veterans were linked to any census or death record information not previously collected and the children's mothers were linked to their childhood censuses. The subsample was designed to over-sample children of ex-POWs. I traced the 
children of all 1,198 ex-POWs who survived to 1900 in the original Union Army and the Andersonville sample. I then drew a subsample of 9,343 non-POWs from the original Union Army sample matched on ex-POW demographic and socioeconomic characteristics at enlistment. The final sample, referred to as the Veterans' Children's Census (VCC) sample, contains 54,568 children. Details about the samples and discussions of potential biases are provided in on-line codebooks, available at NBER's data web page ${ }^{9}$, and also in Costa et al. (2017), Costa (2012), and the supplemental information to Costa et al. (2018). As discussed in the latter, ex-POWs did not marry "down" and their ex-POW status was not correlated with the mortality of their wives.

I used the VCC sample to create a sample of veterans' grandchildren with an oversample of descendants of ex-POWs (NIA R21 AG064460, PI: Costa). I searched for birth and death information of all grandchildren of all ex-POWs and a subsample of grandchildren of non-POWs. I restricted the search to grandchildren of veterans with at least one child who survived to age 45 to obtain a larger sample of grandchildren at lower cost, but I followed all grandchildren regardless of their parent's age at death. The veterans' grandchildren sample contains 1,444 ex-POWs, their 8,190 children, and their 17,015 children and 1,381 non-POWs, their 8,596 children, and 18,6588 children. Birth and death information come from manuscript census records, Find a Grave, the Social Security-death index and applications, WWI and WII draft cards, state vital records (which include birth, marriage, and death indexes), Veterans' Administration records, obituaries, and public records indexes.

I found death dates for $85 \%$ of children and $92 \%$ of grandchildren. I do not examine cause of death because information is missing for $88 \%$ of grandchildren. I am less likely to

\footnotetext{
${ }^{9} \mathrm{See} \mathrm{https//www.nber.org/programs-projects/projects-and-centers/union-army-data} \mathrm{.}$
} 
find a death date if the state has few vital records available on-line. Grandfather's ex-POW status does not predict having a death date.

The mortality pattern at age 10 or older in the sample was similar to that observed for Social security area cohorts even though life expectancy of grandchildren of either sex at age 10 or greater was higher by about a year (Table B1), probably because grandchildren were native-born and were concentrated in the more rural Midwest. Deaths below age 10 are under-reported in the sample, as expected for cohorts born when state vital record keeping was sparse.

Figure A2 shows an association between grandchildren's mortality and grandfathers' non-exchange ex-POW status only after age 45 and only for male-line grandsons. However, I find suggestive evidence that childhood mortality was higher among male-line grandchildren of non-exchange ex-POWs. Ex-POWs of any type had fewer grandchildren of either sex from sons (see Table B3). Compared to a non-POW, the incidence ratio of having a male-line grandchild was 0.8. There was no effect of grandfather's ex-POW status on the number of grandchildren from daughters. Examining veterans' children who were married in 1910 revealed that while the veteran's ex-POW status was not correlated with the number of children ever born reported in the 1910 census, veterans'sons, but not daughters, had a slightly lower fraction of living children if descended from a nonexchange ex-POW rather than a non-POW or an exchange ex-POW (see Table B4). I suspect that any deaths would have been prior to age 10 because deaths prior to this age are not well represented in my sample.

Information on the households in which veterans' children and grandchildren grew up, including the father's occupation and home ownership, is available from linkage to 
the manuscript census records in the Veterans' Children Census samples. All veterans were linked to the 1850-1940 censuses, with the exception of the 1890 census which was destroyed in a fire. Linkage rates of veterans to individual censuses range from $94 \%$ in 1930 to $97 \%$ in 1910 (see Table B2). Veterans' children also were linked to all available 1870-1940 censuses. Among veterans' children who were alive at the time of the census, $86 \%$ were linked to any census and linkage rates to individual censuses range from $94 \%$ in 1870 when children still were in the veteran's household to $83 \%$ in 1940 . I have not linked adult grandchildren to the census; however, grandchildren are in a census because they were in their parents' households. Conditional on being alive and younger than age 18 at the time of the census, linkage rates for grandchildren range from $91 \%$ in 1900 to $96 \%$ in 1940 .

\section{Appendix B: Additional Specifications}

\section{B.1 No Siblings}

When I kept only the eldest grandchild within each line, I found that male-line grandsons of non-exchange ex-POWs were 1.14 times as likely to die at any age after age 45 compared to non-POWs and 1.13 times as likely to die compared to exchange ex-POWs (see Table B5). Statistical significance was higher compared to that reported in Table 4. 


\section{B.2 Early and Late Non-Exchange Ex-POWs, Male-Line Grandsons}

Table B6 reveals that among male-line grandsons it was the descendants of late, not early, exchange ex-POWs who faced a higher mortality risk compared to the descendants of non-POWs. However, the mortality risk of late exchange ex-POWs was statistically indistinguishable from the mortality risk of non-POWs. Low power may be a problem: less than $8 \%$ of male-line grandsons who survived to age 45 were descended from POWs captured in the early days of the war.

\section{B.3 Mothers of Male-Line Grandsons}

I find no evidence that the mothers of male-line grandsons were less hardy, as proxied by motality after age 45, if they married the sons of non-exchange ex-POWs rather than the sons of non-POWs (Table B7). There were no no differences in mortality by father-inlaw's ex-POW status among grandchildren's parents in other lines.

\section{B.4 Ages Transmission}

Grandpaternal ages of 19-24 were particularly sensitive for the transmission of ex-POW stress to male-line grandsons. I estimated a modification of Equation 1 for male-line grandsons,

$$
\beta_{0}+\beta_{1}\left(A_{i} \times P_{N}\right)+\beta_{2}\left(A_{i} \times P_{E}\right)+\beta_{3} C
$$


where $A_{i}$ represents age groups of non-exchange ex-POW captivity risk of 17-18, 19-20, 21-22, 23-24, 25-26, 27-28, 29-30, and 31+, with ages below 17 as the omitted category. Table B8 shows grandfathers who were at risk of being non-exchange ex-POWs at ages 19-20, 21-22, and 23-24 had grandsons whose mortality risk was 1.2 to 1.3 times higher if they were non-exchange ex-POWs rather than non-POWs.

\section{B.5 Mortality and Quarter of Birth Among Grandchildren Descended from Non-POWs}

Table B9 presents hazard ratios for quarter of birth for grandsons and granddaughters descended from non-POWs to compare ancestral with early life risk. Grandsons were 1.07 times more likely to die every age after age 45 if they were born in the second relative to the fourth quarter. Granddaughters were 1.19 and 1.11 times as likely to die every age after age 45 if they were born in the first and second quarters, respectively, relative to the fourth quarter. ${ }^{10}$

\section{B.6 Median Years Lived}

I obtain the difference in median years lived among male-line grandsons by grandfathers' ex-POW status by running Equation 1 using a Gompertz hazards model and then estimating median years lived by grandsons by grandpaternal ex-POW status. See Table B10 for the results.

\footnotetext{
${ }^{10} \mathrm{~A}$ stronger association of quarter of birth with older age mortality among girls relative to boys is consistent with the findings of Gavrilova et al. (2003).
} 


\section{B.7 Occupational Class and Ex-POW Status}

I find suggestive evidence of occupational adjustments to poor health by veterans after the war. Controlling for occupation at enlistment, the probability that non-exchange exPOW veteran grandfathers in 1880 were farmers was 0.09 lower than that of their nonPOW counterparts and their probability of being artisans was 0.05 higher. Results were statistically significant at the $1 \%$ level (see Table B11). Relative to exchange ex-POWs, non-exchange ex-POWs had an 0.063 lower probabilitiy of being farmers and an 0.04 higher probability of being artisans. Ex-POW status did not affect the probability of being laborers or professionals/proprietors in 1880.

The probabilities that veterans' sons and sons-in-law were farmers fell by 0.05 if their fathers or fathers-in-law were non-exchange ex-POWs rather than non-POWs, controlling for the veteran's pre-war characteristics (see Table B12). However, the results were only marginally statistically significant and statistical significance disappeared and the magnitude of the effect was smaller once I controlled for the veteran's occupation in 1880. I found no relationship between the veteran's ex-POW status and his son ever being a laborer or never being a home owner. The absence of a relationship is suggestive of an occupational shift not showing up in socioeconomic status. 
Figure A1: Construction of the Sample

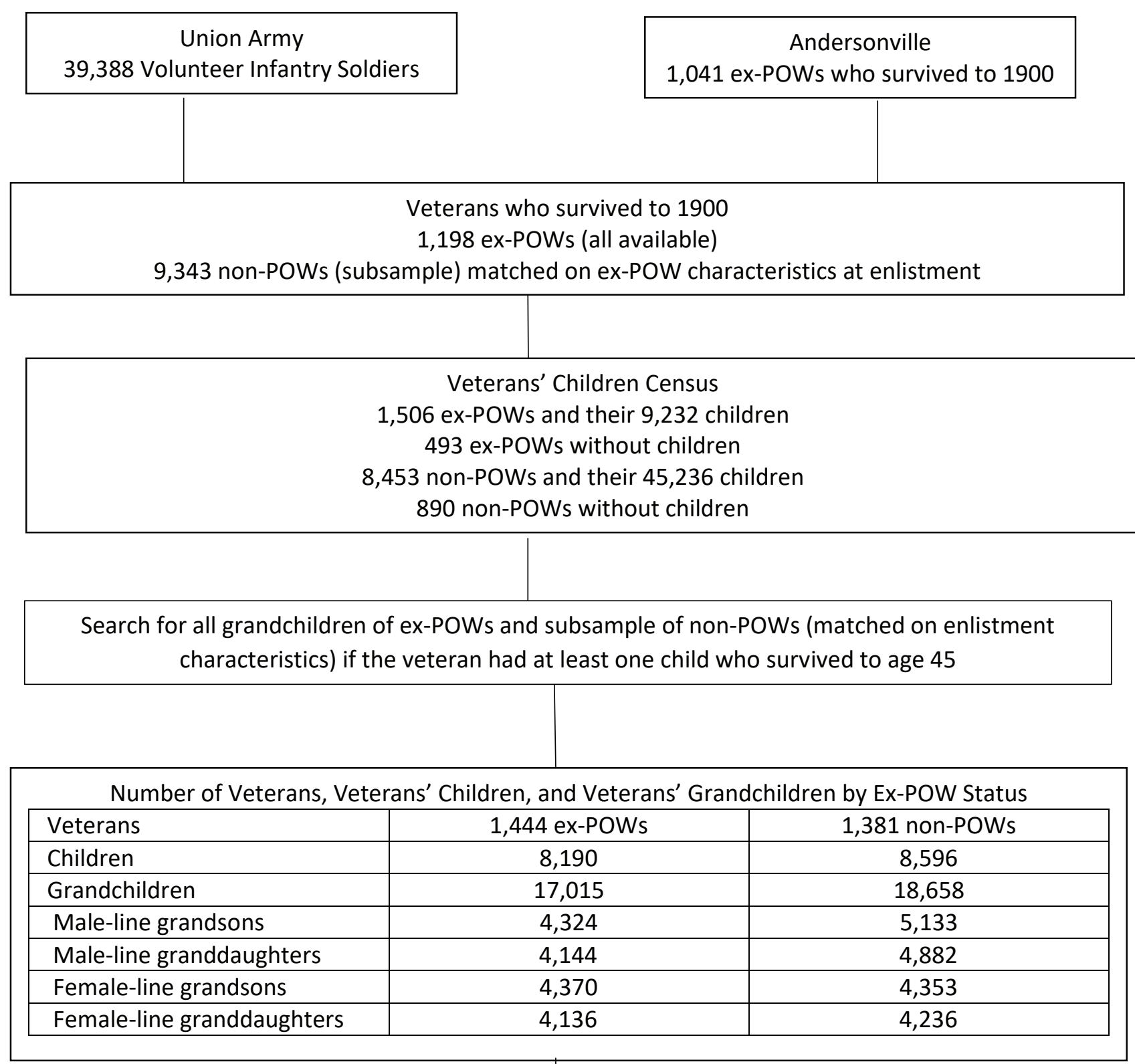

Number in Analytical Sample of Veterans' Grandchildren Surviving to Age 45 and Descended from
Veterans' Children Born after 1866
\begin{tabular}{|l|c|c|}
\hline Veterans & 1,444 ex-POWs & 1,381 non-POWs \\
\hline Children & 6,977 & 6,982 \\
\hline Grandchildren & 11,981 & 12,550 \\
\hline Male-line grandsons & 3,134 & 3,551 \\
\hline Male-line granddaughters & 2,873 & 3,183 \\
\hline Female-line grandsons & 3,144 & 2,997 \\
\hline Female-line granddaughters & 2,828 & 2,816 \\
\hline
\end{tabular}


Figure A2: Grandchildrens' Survival Curves by Grandfather's Ex-POW Status
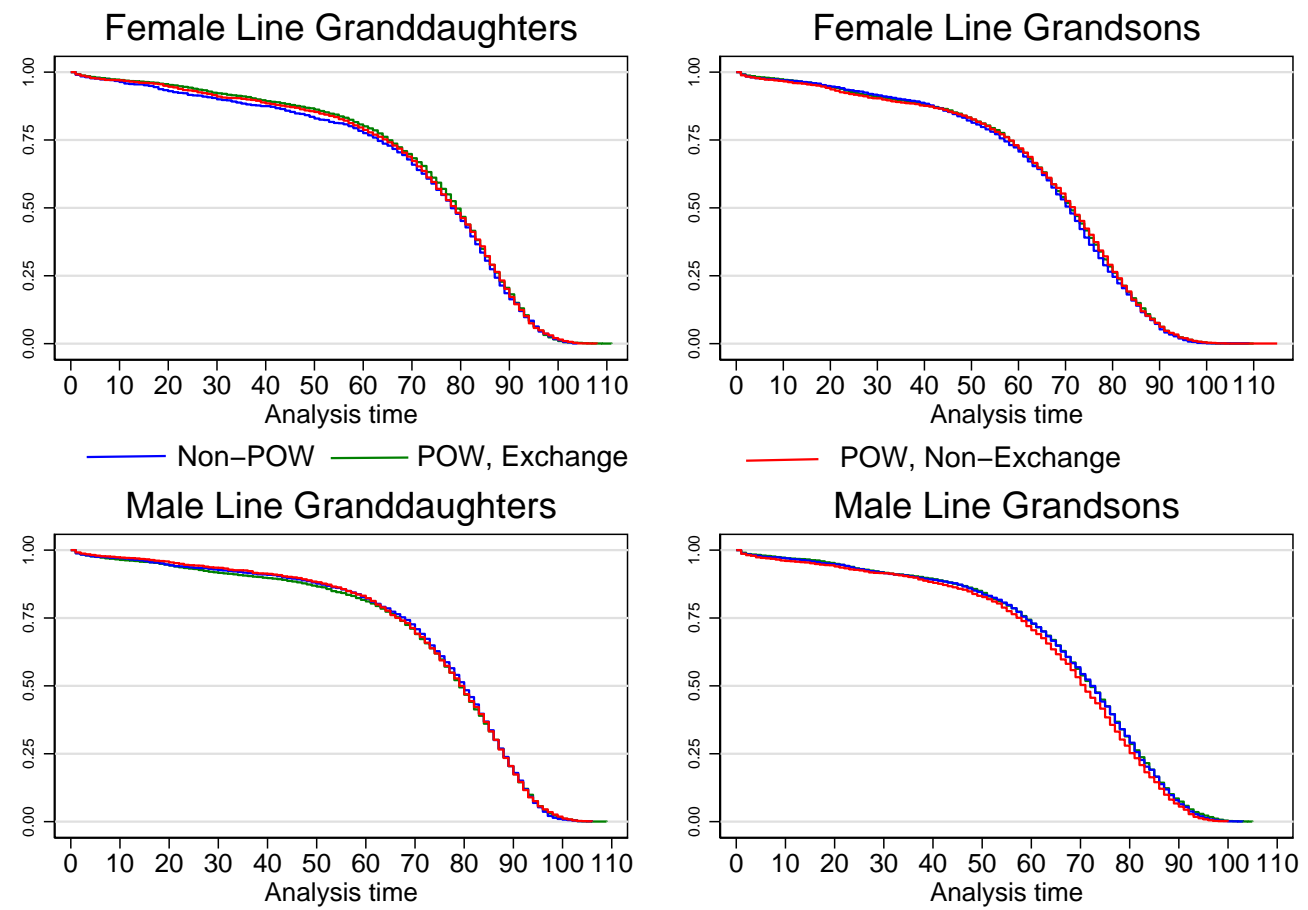

Kaplan Meier survival curves estimated for years lived from birth until death. 
Table B1: Life Expectancy by Cohort and Sex, Veterans' Grandchildren and US Population

\begin{tabular}{|c|c|c|c|c|}
\hline & \multicolumn{2}{|c|}{ Veterans' Grandchildren } & \multicolumn{2}{|c|}{ Social Security Area } \\
\hline & $\begin{array}{c}\text { b. } 1890- \\
1909\end{array}$ & $\begin{array}{c}\text { b. } 1910- \\
1930\end{array}$ & b. 1910 & b. 1920 \\
\hline \multicolumn{5}{|l|}{ Men } \\
\hline Age 0 & 67 & 69 & 56 & 62 \\
\hline 10 & 59 & 61 & 58 & 60 \\
\hline 20 & 50 & 52 & 49 & 51 \\
\hline 30 & 42 & 44 & 41 & 43 \\
\hline 40 & 33 & 34 & 32 & 34 \\
\hline 50 & 25 & 26 & 24 & 26 \\
\hline 60 & 17 & 19 & 17 & 18 \\
\hline 70 & 11 & 13 & 12 & 12 \\
\hline 80 & 8 & 8 & 7 & 7 \\
\hline \multicolumn{5}{|l|}{ Women } \\
\hline Age 0 & 74 & 76 & 64 & 69 \\
\hline 10 & 66 & 68 & 65 & 67 \\
\hline 20 & 58 & 59 & 56 & 58 \\
\hline 30 & 50 & 50 & 48 & 50 \\
\hline 40 & 41 & 41 & 39 & 40 \\
\hline 50 & 33 & 32 & 30 & 31 \\
\hline 60 & 24 & 24 & 22 & 23 \\
\hline 70 & 17 & 16 & 15 & 15 \\
\hline 80 & 12 & 10 & 9 & 9 \\
\hline
\end{tabular}

Social Security Area life expectancies are from Bell and Miller (2005). 
Table B2: Linkage Rates for Veterans, Veterans' Children, and Veterans' Grandchildren

\begin{tabular}{rrrr}
\hline & & $\begin{array}{c}\text { Child of } \\
\text { Veteran } \\
\text { b. 1866+ }\end{array}$ & $\begin{array}{c}\text { Grandchild } \\
\text { of } \\
\text { Veteran }\end{array}$ \\
\hline $\begin{array}{l}\text { Percentage } \\
\text { with death year }\end{array}$ & 100.0 & 84.8 & 91.5 \\
linked to Census of & & & \\
1850 & 95.5 & & \\
1860 & 95.5 & & \\
1870 & 95.5 & 93.6 & \\
1880 & 95.5 & 86.3 & \\
1900 & 96.4 & 89.3 & 90.8 \\
1910 & 96.5 & 87.2 & 93.9 \\
1920 & 94.5 & 87.5 & 91.7 \\
1930 & 94.3 & 88.7 & 93.9 \\
1940 & 100.0 & 83.1 & 96.1 \\
linked to any Census & 97.7 & 85.6 & 92.1 \\
\hline
\end{tabular}

Linkage rates are for the living only and, in the case of grandchildren, for those age 0-17 at the time of the census. 
Table B3: Grandfather Ex-POW Status and Number of Grandchildren by Type

\begin{tabular}{lcccc}
\hline & \multicolumn{2}{c}{ Male-line } & \multicolumn{2}{c}{ Female-line } \\
\cline { 2 - 5 } & $\begin{array}{c}\text { Grand- } \\
\text { sons }\end{array}$ & $\begin{array}{c}\text { Grand- } \\
\text { daughters }\end{array}$ & $\begin{array}{c}\text { Grand- } \\
\text { sons }\end{array}$ & $\begin{array}{c}\text { Grand- } \\
\text { daughters }\end{array}$ \\
\hline $\begin{array}{c}\text { Grandfather was } \\
\text { Non-POW }\end{array}$ & 1.000 & 1.000 & 1.000 & 1.000 \\
Exchange Ex-POW & $0.799 * * *$ & $0.817 * * *$ & $0.950 *$ & 0.953 \\
Non-exchange Ex-POW & $(0.024)$ & $(0.025)$ & $(0.029)$ & $(0.029)$ \\
& $(0.024)$ & $(0.026)$ & $(0.030)$ & $(0.031)$ \\
\hline
\end{tabular}

2,825 observations. Results are from Poisson regressions and include controls for characteristics at enlistment. Coefficients are incident ratios. Robust standard errors are in parentheses. The symbols *, **, and *** indicate significance at the 10,5 , and 1 percent level. 
Table B4: Father's Ex-POW Status and Number of Births and Fraction of Children Surviving Reported in 1910

\begin{tabular}{|c|c|c|c|c|}
\hline & \multicolumn{2}{|c|}{$\begin{array}{l}\text { Number of Children } \\
\text { Ever Born }\end{array}$} & \multicolumn{2}{|c|}{$\begin{array}{c}\text { Fraction of Children } \\
\text { Surviving }\end{array}$} \\
\hline & Sons & Daughters & Sons & Daughters \\
\hline $\begin{array}{l}\text { Grandfather was } \\
\text { Non-POW }\end{array}$ & & & & \\
\hline Exchange Ex-POW & $\begin{array}{c}0.982 \\
(0.033) \\
{[0.587]}\end{array}$ & $\begin{array}{c}1.014 \\
(0.036) \\
{[0.702]}\end{array}$ & $\begin{array}{l}-0.004 \\
(0.012) \\
{[0.745]}\end{array}$ & $\begin{array}{c}0.005 \\
(0.011) \\
{[0.639]}\end{array}$ \\
\hline Non-exchange Ex-POW & $\begin{array}{c}0.997 \\
(0.035) \\
{[0.928]}\end{array}$ & $\begin{array}{c}0.986 \\
(0.036) \\
{[0.701]}\end{array}$ & $\begin{array}{c}-0.023^{*} \\
(0.013) \\
{[0.083]}\end{array}$ & $\begin{array}{l}-0.003 \\
(0.011) \\
{[0.799]}\end{array}$ \\
\hline
\end{tabular}

3,072 married sons and 2,971 married daughters of veterans in 1910. The number of children and the number of living children was asked of married women only. Coefficients for the first two regressions are incident ratios from Poisson regressions. Coefficients for the last two regressions are from OLS regressions. All regressions control for the veteran's enlistment characteristics and cluster the standard errors on the veteran. The symbols *, **, and *** indicate significance at the 10,5 , and 1 percent level. 
Table B5: Grandchildren's Hazard Ratios of Mortality by Grandfather's Ex-POW Status Among Oldest Grandchild Within Each Line

\begin{tabular}{lcccc}
\hline & \multicolumn{2}{c}{ Male-line } & \multicolumn{2}{c}{ Female-line } \\
\cline { 2 - 5 } & $\begin{array}{c}\text { Grand- } \\
\text { sons }\end{array}$ & $\begin{array}{c}\text { Grand- } \\
\text { daughters }\end{array}$ & $\begin{array}{c}\text { Grand- } \\
\text { sons }\end{array}$ & $\begin{array}{c}\text { Grand- } \\
\text { daughters }\end{array}$ \\
\hline Grandfather was & 1.000 & 1.000 & 1.000 & 1.000 \\
Non-POW & & & & \\
Exchange Ex-POW & 1.012 & 1.020 & 1.054 & 1.025 \\
& $(0.049)$ & $(0.054)$ & $(0.051)$ & $(0.055)$ \\
Non-exchange Ex-POW & {$[0.813]$} & {$[0.710]$} & {$[0.276]$} & {$[0.645]$} \\
& $1.143 * * *$ & 1.015 & 1.015 & 1.059 \\
& $(0.059)$ & $(0.057)$ & $(0.057)$ & $(0.057)$ \\
& {$[0.009]$} & {$[0.786]$} & {$[0.799]$} & {$[0.286]$} \\
Non-exchange Ex-POW & & & & \\
relative to Exchange Ex-POW & $1.130 * *$ & 0.996 & 0.962 & 1.033 \\
& $(0.055)$ & $(0.054)$ & $(0.050)$ & $(0.054)$ \\
& {$[0.013]$} & {$[0.934]$} & {$[0.456]$} & {$[0.539]$} \\
& 4.03 & 7.25 & 19.36 & 10.01 \\
Test of proportional hazards & {$[0.998]$} & {$[0.950]$} & {$[0.198]$} & {$[0.819]$} \\
assumption, $\chi^{2}$, Pr $>\chi^{2}(15)$ & 3,108 & 2,948 & 2,738 & 2,591 \\
\hline Observations & & &
\end{tabular}

The samples are restricted to the estimated for years lived from birth until death oldest sibling within each line. Estimated from a Cox proportional hazards model using years lived after age 45, stratifying on birth cohort, and controlling for birth year and the veteran's enlistment year, occupation at enlistment (farmer, artisan, laborer, professional or proprietor, and unknown), enlistment in a city with population of 50,000 or more, born in the US, wounded in the war, and in the original Union Army sample. Standard errors, clustered on the veteran are in parenthesis. $\mathrm{P}$ values are in square brackets. The proportional hazards assumption is tested using the Schoenfeld residuals. The symbols *, **, and $* * *$ indicate significance at the 10,5 , and 1 percent level. 
Table B6: Male-Line Grandchildren's Hazard Ratios of Mortality by Grandfather's ExPOW Status

\begin{tabular}{lcc}
\hline $\begin{array}{l}\text { Grandfather's } \\
\text { ex-POW status }\end{array}$ & $\begin{array}{c}\text { Grandfathers } \\
\text { Risk Non-Exchange Ex-POW } \\
\text { at Ages 17-24 }\end{array}$ \\
\hline Non-POW & 1.000 & 1.000 \\
Exchange Ex-POW, Early Capture & 0.993 & 1.088 \\
& $(0.047)$ & $(0.064)$ \\
Non-exchange Ex-POW & {$[0.889]$} & {$[0.152]$} \\
& $1.11 *^{* *}$ & $1.218^{* * *}$ \\
Exchange Ex-POW, Late Capture & $(0.047)$ & $(0.061)$ \\
& {$[0.008]$} & {$[0.000]$} \\
Non-exchange Ex-POW & 1.056 & $1.134 * *$ \\
relative to Early Exchange Ex-POW & $(0.050)$ & $(0.065)$ \\
& {$[0.255]$} & {$[0.028]$} \\
Non-exchange Ex-POW & $1.126 * *$ & $1.119 *$ \\
relative to Late Exchange Ex-POW & $(0.058)$ & $(0.068)$ \\
& 1.059 & {$[0.063]$} \\
Late Exchange Ex-POW & {$[0.200]$} & 1.074 \\
relative to Early Exchange Ex-POW & 1.063 & $(0.056)$ \\
Test of proportional hazards & {$[0.275]$} & {$[0.173]$} \\
assumption, $\chi^{2}$, Pr $>\chi^{2}(16)$ & 15.33 & 1.042 \\
Observations & {$[0.500]$} & $(0.069)$ \\
\hline
\end{tabular}

Estimated from a Cox proportional hazards model using years lived after age 45, stratifying on birth cohort, and controlling for birth year and the veteran's enlistment year, occupation at enlistment (farmer, artisan, laborer, professional or proprietor, and unknown), enlistment in a city with population of 50,000 or more, born in the US, wounded in the war, and in the original Union Army sample. Standard errors, clustered on the veteran are in parenthesis. P values are in square brackets. The proportional hazards assumption is tested the Schoenfeld residuals. The symbols *, **, and $* * *$ indicate significance at the 10,5 , and 1 percent level. 
Table B7: Hazard Ratios of Mortality After Age 45 for Fathers and Mothers of Grandchildren Within Each Line by Father-In-Law's Ex-POW Status

\begin{tabular}{|c|c|c|c|c|}
\hline & \multicolumn{2}{|c|}{$\begin{array}{l}\text { Mothers of } \\
\text { Male-line }\end{array}$} & \multicolumn{2}{|c|}{$\begin{array}{c}\text { Fathers of } \\
\text { Female-line }\end{array}$} \\
\hline & $\begin{array}{l}\text { Grand- } \\
\text { sons }\end{array}$ & $\begin{array}{l}\text { Grand- } \\
\text { daughters }\end{array}$ & $\begin{array}{l}\text { Grand- } \\
\text { sons }\end{array}$ & $\begin{array}{l}\text { Grand- } \\
\text { daughters }\end{array}$ \\
\hline \multicolumn{5}{|l|}{ Veterans's Ex-POW status } \\
\hline Non-POW & 1.000 & 1.000 & 1.000 & 1.000 \\
\hline \multirow[t]{3}{*}{ Exchange Ex-POW } & $1.172 *$ & 1.023 & 1.042 & 1.044 \\
\hline & $(0.098)$ & $(0.094)$ & $(0.088)$ & $(0.085)$ \\
\hline & [0.057] & [0.807] & {$[0.627]$} & [0.597] \\
\hline \multirow[t]{3}{*}{ Non-exchange Ex-POW } & 1.043 & 1.022 & 0.997 & 0.975 \\
\hline & $(0.081)$ & $(0.090)$ & $(0.092)$ & $(0.082)$ \\
\hline & {$[0.584]$} & {$[0.805]$} & [0.974] & {$[0.763]$} \\
\hline \multirow{4}{*}{$\begin{array}{l}\text { Non-exchange Ex-POW } \\
\text { relative to Exchange Ex-POW }\end{array}$} & & & & \\
\hline & 0.89 & 0.999 & 0.957 & 0.934 \\
\hline & $(0.068)$ & $(0.089)$ & $(0.079)$ & $(0.079)$ \\
\hline & {$[0.125]$} & {$[0.995]$} & [0.592] & {$[0.418]$} \\
\hline Test of proportional hazards & 14.09 & 22.95 & 60.4 & 37.38 \\
\hline assumption, $\chi^{2}, \operatorname{Pr}>\chi^{2}(15)$ & [0.169] & {$[0.011]$} & {$[0.000]$} & {$[0.000]$} \\
\hline Observations & 3,467 & 2,926 & 3,477 & 3,095 \\
\hline
\end{tabular}

The fathers and mothers in the sample are not related to the veteran. Estimated from Cox proportional hazards models using years lived after age 45, stratifying on veterans' enlistment characteristics and whether in the Union Army sample, and controlling for own birth year and the veteran's, occupation at enlistment (farmer, artisan, laborer, professional or proprietor, and unknown), enlistment in a city with population of 50,000 or more, born in the US, and wounded in the war. Standard errors, clustered on the veteran are in parenthesis. P values are in square brackets. The proportional hazards assumption is tested using the Schoenfeld residuals. The symbols *, **, and *** indicate significance at the 10,5 , and 1 percent level. 
Table B8: Hazard Ratios of Mortality after Age 45 Among Male-Line Grandsons By At Risk Age Group

\begin{tabular}{|c|c|c|c|c|c|c|}
\hline \multirow{3}{*}{$\begin{array}{l}\text { At Risk } \\
\text { Age } \\
\text { Group }\end{array}$} & \multicolumn{6}{|c|}{ Grandfather was Non-Exchange Ex-POW Relative to } \\
\hline & \multicolumn{3}{|c|}{ Non-POW } & \multicolumn{3}{|c|}{ Exchange Ex-POW } \\
\hline & $\begin{array}{c}\text { Hazard } \\
\text { Ratio }\end{array}$ & $\begin{array}{l}\text { Std. } \\
\text { Err. }\end{array}$ & $\begin{array}{c}\text { P- } \\
\text { Value }\end{array}$ & $\begin{array}{l}\text { Hazard } \\
\text { Hazard }\end{array}$ & $\begin{array}{l}\text { Std. } \\
\text { Std. }\end{array}$ & $\begin{array}{l}\text { P- } \\
\text { P- }\end{array}$ \\
\hline$<17$ & 0.874 & 0.170 & 0.489 & 0.846 & 0.213 & 0.507 \\
\hline $17-18$ & 1.025 & 0.086 & 0.768 & 1.035 & 0.084 & 0.669 \\
\hline $19-20$ & $1.216^{* *}$ & 0.103 & 0.022 & 1.115 & 0.101 & 0.229 \\
\hline $21-22$ & $1.283 * * *$ & 0.106 & 0.002 & 0.988 & 0.097 & 0.900 \\
\hline $23-24$ & $1.228^{* *}$ & 0.123 & 0.039 & $1.258^{* *}$ & 0.124 & 0.020 \\
\hline $25-26$ & 0.862 & 0.118 & 0.278 & 1.045 & 0.147 & 0.756 \\
\hline $27-28$ & 0.906 & 0.112 & 0.426 & 0.880 & 0.138 & 0.414 \\
\hline $29-30$ & 1.163 & 0.251 & 0.486 & 1.345 & 0.394 & 0.312 \\
\hline$\geq 31$ & 0.907 & 0.152 & 0.560 & 0.995 & 0.175 & 0.978 \\
\hline
\end{tabular}

At Risk=at risk of being a non-exchange ex-POW. Estimated from a Cox proportional hazards model using years lived after age 45. Stratification is on birth cohort. Controls include birth year and the veteran's enlistment year, occupation at enlistment (farmer, artisan, laborer, professional or proprietor, and unknown), enlistment in a city with population of 50,000 or more, born in the US, wounded in the war, and in the original Union Army sample. Standard errors are clustered on the veteran. A test of the proportional hazards assumption using the Schoenfeld residuals yielded $\chi^{2}=41.76, \operatorname{Pr}>\chi^{2}(39)=0.352$ The symbols $*, * *$, and $* * *$ indicate significance at the 10,5 , and 1 percent level. 
Table B9: Hazard Ratios of Mortality after Age 45 Among Grandchildren of Non-POWs by Quarter of Birth

\begin{tabular}{lcc}
\hline & $\begin{array}{c}\text { Grand- } \\
\text { sons }\end{array}$ & $\begin{array}{c}\text { Grand- } \\
\text { daughters }\end{array}$ \\
\hline Born in & & \\
First quarter & 1.041 & $1.188^{* * *}$ \\
& $(0.037)$ & $(0.043)$ \\
Second quarter & {$[0.259]$} & {$[0.000]$} \\
& $1.069^{* *}$ & $1.113^{* * *}$ \\
& $(0.036)$ & $(0.042)$ \\
Third quarter & {$[0.048]$} & {$[0.005]$} \\
& 1.047 & 1.051 \\
& $(0.036)$ & $(0.038)$ \\
Fourth quarter & {$[0.180]$} & {$[0.166]$} \\
Test of proportional hazards & 1.000 & 1.000 \\
$\quad$ & 14.66 & 16.78 \\
assumption, 13 df & {$[0.329]$} & {$[0.209]$} \\
Observations & & \\
\hline
\end{tabular}

Estimated from a Cox proportional hazards model using years lived after age 45 for grandchildren of non-POWs. Stratification is on birth cohort. Controls include birth year and the veteran's enlistment year, occupation at enlistment (farmer, artisan, laborer, professional or proprietor, and unknown), enlistment in a city with population of 50,000 or more, born in the US, wounded in the war, and in the original Union Army sample. Standard errors, clustered on the veteran are in parentheses. P values are in square brackets. The symbols *,**, and $* * *$ indicate significance at the 10 , 5 , and 1 percent level. 
Table B10: Mortality after Age 45 Among Male-Line Grandsons of Non-POWs, Gompertz Specification

\begin{tabular}{lcccc}
\hline Grandfathers: & \multicolumn{2}{c}{ All } & \multicolumn{2}{c}{ At Risk at Age 17-24 } \\
\hline Grandfather's & $\begin{array}{c}\text { Regression } \\
\text { Coefficients }\end{array}$ & $\begin{array}{c}\text { Median } \\
\text { Years Lived }\end{array}$ & $\begin{array}{c}\text { Regression } \\
\text { Coefficients }\end{array}$ & $\begin{array}{c}\text { Median } \\
\text { Years Lived }\end{array}$ \\
Non-POW (omitted) & 0.000 & $29.900^{* * *}$ & 0.000 & $30.261^{* * *}$ \\
& & $(0.286)$ & & $(0.393)$ \\
Exchange Ex-POW & & {$[0.000]$} & & {$[0.000]$} \\
& 0.030 & $29.558^{* * *}$ & $0.113 * *$ & $28.980 * * *$ \\
Non-exchange Ex-POW & $(0.040)$ & $(0.361)$ & $(0.049)$ & $(0.425)$ \\
& {$[0.455]$} & {$[0.000]$} & {$[0.022]$} & {$[0.000]$} \\
& $0.107 * *$ & $28.671 * * *$ & $0.196 * * *$ & $28.037 * *$ \\
Difference Non-exchange Ex-POW & $(0.043)$ & $(0.397)$ & $(0.051)$ & $(0.437)$ \\
and Exchange Ex-POW & {$[0.012]$} & {$[0.000]$} & {$[0.000]$} & {$[0.000]$} \\
& $0.078 *$ & $0.887 *$ & $0.083 *$ & $0.943 *$ \\
Difference Non-exchange Ex-POW & $(0.040)$ & $(0.462)$ & $(0.047)$ & $(0.526)$ \\
and Non-POW & {$[0.055]$} & {$[0.055]$} & {$[0.073]$} & {$[0.073]$} \\
& & $1.229 * *$ & & $2.224 * * *$ \\
Difference Exchange Ex-POW & & $(0.488)$ & & $(0.578)$ \\
and Non-POW & & {$[0.012]$} & & {$[0.000]$} \\
& & 0.341 & & $1.281 * *$ \\
Observations & & $(0.457)$ & & $(0.559)$ \\
\hline
\end{tabular}

At risk = at risk of being a non-exchange ex-POW. Estimated from a Gompertz hazards model using years lived after age 45. Stratification is on birth cohort. Controls include birth year and the veteran's enlistment year, occupation at enlistment (farmer, artisan, laborer, professional or proprietor, and unknown), enlistment in a city with population of 50,000 or more, born in the US, wounded in the war, and in the original Union Army sample. Standard errors, clustered on the veteran are in parentheses. P values are in square brackets. The symbols *, **, and *** indicate significance at the 10,5 , and 1 percent level. 
Table B11: Veteran's Occupational Class in 1880 and His Ex-POW Status (Odds Ratios)

\begin{tabular}{lcccc}
\hline Veteran's 1880 Occupational Class: & Farmer & $\begin{array}{l}\text { Professional/ } \\
\text { Proprietor }\end{array}$ & Artisan & Laborer \\
\hline Veteran was & & & & \\
Non-POW (omitted) & 0.000 & 0.000 & 0.000 & 0.000 \\
Exchange Ex-POW & -0.027 & 0.023 & 0.016 & -0.012 \\
& $(0.026)$ & $(0.016)$ & $(0.018)$ & $(0.022)$ \\
& {$[0.298]$} & {$[0.153]$} & {$[0.379]$} & {$[0.587]$} \\
Non-exchange Ex-POW & $-0.090^{* * *}$ & 0.027 & $0.053^{* * *}$ & 0.010 \\
& $(0.027)$ & $(0.017)$ & $(0.020)$ & $(0.024)$ \\
Non-exchange Ex-POW & {$[0.001]$} & {$[0.125]$} & {$[0.009]$} & {$[0.692]$} \\
relative to Exchange Ex-POW & $-0.063^{* *}$ & 0.003 & $0.038^{*}$ & 0.022 \\
& $(0.026)$ & $(0.018)$ & $(0.020)$ & $(0.022)$ \\
& {$[0.016]$} & {$[0.848]$} & {$[0.055]$} & {$[0.346]$} \\
\hline
\end{tabular}

2,423 observations. Results are the marginals from a multinomial probit in which the four occupational categories are farmer, professional or proprietor, artisan, and laborer. Additional control variables include the veteran's birth year, enlistment year dummies, occupation at enlistment (farmer, artisan, laborer, professional or proprietor, and unknown), enlistment in a city with population of 50,000 or more, born in the US, wounded in the war, and in the original Union Army sample. Standard errors are in parentheses and p-values are in square brackets. The symbols *, **, and *** indicate significance at the 10,5 , and 1 percent level. 
Table B12: Veterans’ Ex-POW Status and Children's Socioeconomic Status

\begin{tabular}{ccccccc}
\hline & \multicolumn{2}{c}{ Veterans' Sons Were } & \multicolumn{2}{c}{ Veterans' Sons-in-Law Were } \\
\hline & $\begin{array}{c}\text { Ever } \\
\text { Laborers }\end{array}$ & $\begin{array}{c}\text { Ever } \\
\text { Farmers }\end{array}$ & $\begin{array}{c}\text { Never } \\
\text { Home } \\
\text { Owners }\end{array}$ & $\begin{array}{c}\text { Ever } \\
\text { Laborers }\end{array}$ & $\begin{array}{c}\text { Ever } \\
\text { Farmers }\end{array}$ & $\begin{array}{c}\text { Never } \\
\text { Home } \\
\text { Owners }\end{array}$ \\
\hline Veteran was & & & & & & \\
Non-POW (omitted) & 0.000 & 0.000 & 0.000 & 0.000 & 0.000 & 0.000 \\
Exchange Ex-POW & 0.004 & -0.024 & 0.008 & -0.015 & -0.030 & -0.004 \\
& $(0.027)$ & $(0.026)$ & $(0.022)$ & $(0.025)$ & $(0.027)$ & $(0.022)$ \\
& {$[0.896]$} & {$[0.362]$} & {$[0.718]$} & {$[0.535]$} & {$[0.271]$} & {$[0.873]$} \\
Non-exchange Ex-POW & 0.017 & $-0.053 *$ & 0.019 & -0.019 & $-0.052^{*}$ & 0.004 \\
& $(0.026)$ & $(0.027)$ & $(0.024)$ & $(0.025)$ & $(0.027)$ & $(0.023)$ \\
& {$[0.521]$} & {$[0.053]$} & {$[0.418]$} & {$[0.455]$} & {$[0.057]$} & {$[0.879]$} \\
Non-exchange Ex-POW & & & & & & \\
relative to Exchange Ex-POW & 0.013 & -0.029 & 0.011 & -0.003 & -0.022 & 0.008 \\
& $(0.026)$ & $(0.027)$ & $(0.023)$ & $(0.024)$ & $(0.026)$ & $(0.222)$ \\
& {$[0.608]$} & {$[0.268]$} & {$[0.635]$} & {$[0.896]$} & {$[0.393]$} & {$[0.753]$} \\
\hline
\end{tabular}

4,261 observations for the regressions for sons and 3,767 observations for the regressions for sons-in-law. Results are from the marginals from probits and additional control variables include the birth year of the veteran's child and veteran's enlistment year dummies, occupation at enlistment (farmer, artisan, laborer, professional or proprietor, and unknown), enlistment in a city with population of 50,000 or more, born in the US, wounded in the war, and in the original Union Army sample. Standard errors, clustered on the veteran, are in parentheses and p-values are in square brackets. The symbols *,**, and *** indicate significance at the 10, 5, and 1 percent level. 